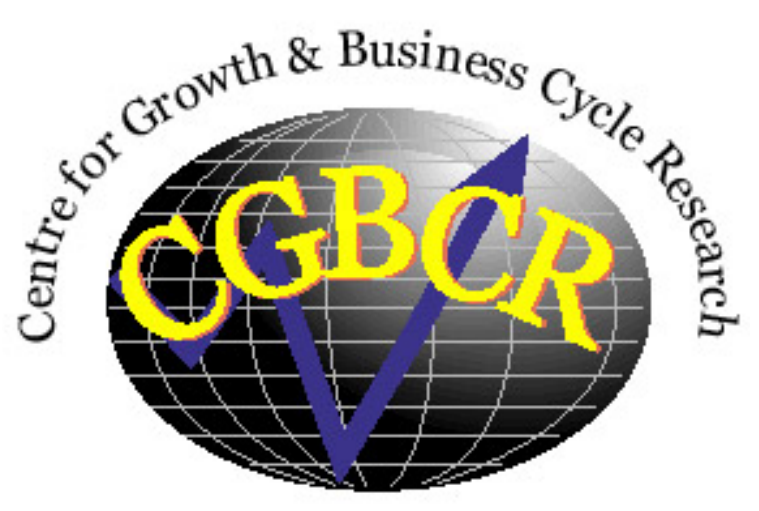

Discussion Paper Series

\title{
Financial Dollarization: Short-Run Determinants in Transition Economies \\ By
}

Kyriakos C. Neanidis and Christos S. Savva

Centre for Growth and Business Cycle Research, Economic Studies,

University of Manchester, Manchester, M13 9PL, UK

February 2009

Number 113

Download paper from:

http://www.socialsciences.manchester.ac.uk/cgbcr/discussionpape rs/index.html 


\title{
Financial Dollarization: Short-Run Determinants in Transition Economies
}

\author{
Kyriakos C. Neanidis ${ }^{a}$ and Christos S. Savva \\ ${ }^{a}$ Centre for Growth and Business Cycle Research, Economics, University of Manchester \\ ${ }^{\mathrm{b}}$ Economics Research Centre, University of Cyprus
}

\begin{abstract}
This paper examines the determinants of financial dollarization in transition economies from a short-run perspective. Using monthly data of deposit and loan dollarization we study the drivers of short-term fluctuations in dollarization and test their importance at different levels of dollarization. The results provide evidence that (a) the positive short-run effects of depreciation on deposit dollarization are exacerbated in high-dollarization countries; (b) short-run loan dollarization is mainly driven by banks matching of domestic loans and deposits, international financial integration, and institutional quality; and (c) both types of dollarization are affected by interest rate differentials and deviations from desired dollarization.
\end{abstract}

JEL Classification: E44; F31; G11; G20

Keywords: Currency Risk; Financial Dollarization; Short-Run Variations; Transition Economies 


\section{Introduction}

Financial dollarization (FD) has been the subject of considerable research over the past two decades. This research has led to the broad consensus that financial dollarization in the presence of large exchange rate fluctuations can become a potential source of balance of payments and financial crises, and pose a serious threat to macroeconomic and financial stability. These reasons have led to the examination of the determinants of financial dollarization as a way of improving our understanding of its development. In this paper we contribute to the literature by providing an empirical analysis of the drivers of short-term variations in both deposit (DD) and loan dollarization (LD) in transition economies. ${ }^{1}$

The majority of the studies conducted in the literature have had as a goal to investigate the determinants of long-run dollarization by mostly focusing on foreign currency-denominated deposits. In a recent survey of the literature, De Nicolo et al. (2003) and Levy-Yeyati (2006) summarize the main drivers of deposit dollarization. These are the past rate of inflation according to the currency substitution view (e.g., Savastano 1996; Sahay and Vegh 1996), the minimum variance portfolio (mvp) dollarization share according to the portfolio view (e.g., Ize and Levy-Yeyati 2003), and the quality of institutions and the exchange rate pegs according to the institutional view (e.g., De Nicolo et al. 2003; Rennhack and Nozaki 2006).

Only recently researchers have re-oriented their attention on the causal factors of loan dollarization or jointly examined both types of dollarization, again within a long-run perspective. Catão and Terrones (2000) represent an early work that develops a theoretical model of FD with a focus on the banking side. Barajas and Morales (2003) and Arteta (2005) evaluate the effects of exchange rate policy on FD. The first study finds that DD greatly influences LD as banks shift currency risk to their borrowers in Latin America. It also shows that central bank intervention in the foreign exchange market increases loan dollarization. The latter finding is in contrast to Arteta (2005) who shows that floating exchange rate regimes encourage both DD and LD but more strongly

\footnotetext{
${ }^{1}$ As typical in the literature, deposit dollarization represents the ratio of foreign currency deposits to total deposits of residents at domestic banks, while loan (or credit) dollarization reflects the ratio of foreign currency loans to total loans of domestic banks to residents.
} 
DD so that bank currency mismatches are the overall outcome. More recently Luca and Petrova (2008) have produced evidence of banks' desire for currency matched portfolios beyond regulatory requirements, as Barajas and Morales (2003) did but, for a set of transition economies. They also show that increases in banks' net foreign assets adversely influence loan dollarization. Basso et al. (2007), on the other hand, represents a study that examines both types of dollarization. By developing a theory model that is tested for transition economies, the authors unveil the importance of interest rate differentials and of the presence of foreign banks in the local financial sector.

Our paper differs from the existing literature in an essential way. We examine the drivers of short-run variations in both deposit and loan dollarization. We are particularly interested to the response of dollarization to exchange rate changes, changes in monetary expansion and the banks' short-run currency matching behaviour of loans and deposits, while controlling for the most important drivers found in the literature. The investigation further takes account of differences in the determinants of short-run DD and LD at different degrees of dollarization. In this way we consider the potentially asymmetric response of depositors and banks at high dollarization environments due to the different portfolio instruments available to them. As Luca and Petrova (2008) and Basso et al. (2007), we limit our interest to transition economies as the circulation of foreign currency has been increasing in importance in these countries - over 1993-2006 foreign currencydenominated deposits averaged $40 \%$ and loans $48 \%$.

Our analysis complements and is most closely related to Honohan (2007) who examines the determinants of short-run fluctuations in deposit dollarization for a set of developing countries by paying particular attention to the effects of currency depreciation. He, however, ignores the examination of the short-run drivers of LD and avoids testing whether the effects of these factors differ in situations of highdollarization. Accounting for these considerations allow us to provide information about the short-run behavior of banks and test the response of depositors and banks when dollarization rises.

The empirical evidence we obtain is supportive of the following. First, the positive (negative) short-run effects of depreciation (monetary expansion) on deposit dollarization are exacerbated in countries with high dollarization, while such a 
phenomenon is absent in the case of loan dollarization. Second, short-run loan dollarization is mainly driven by banks matching of domestic loans and deposits. This means that loan dollarization is positively correlated with deposit dollarization. Third, short-run loan dollarization is also, but to a smaller extent, diminished by international financial integration and institutional quality, and finally, both short-run deposit and loan dollarization are affected by interest rate differentials and deviations from desired dollarization. These findings are robust to a wide range of sensitivity tests, including the use of alternative estimation techniques, regression specifications, instrumentation strategies, and measurement approaches.

The remainder of the paper is organized as follows. Section 2 describes the estimation methodology and the data set. Section 3 presents the main findings of the analysis, while section 4 reports on the results of extensive robustness tests. Finally, section 5 concludes.

\section{Methodology and Data}

Our main objective is to examine the short-run determinants of FD in transition economies. We take a broad view by evaluating both sides of the financial intermediaries' balance sheet, and, thereby, examine independently the determinants of both DD and LD.

\subsection{Empirical Strategy and Methodology}

Our estimation strategy, in terms of the choice of potential determinants of FD, is driven by the existing literature, as outlined in the introduction. We wish to draw attention, however, to the short-run determinants of FD given the limited empirical work on this front. Given our main interest, the benchmark regression specifications for changes in DD and LD are

$$
\Delta D D_{i t}=\alpha_{0}+\beta_{1} e r f_{i t}+\beta_{2} m b f_{i t}+\beta_{3} e c_{i t}+\sum_{j=1}^{m} \gamma_{j} X_{j, i t}+\varepsilon_{i t},
$$


$\Delta L D_{i t}=\alpha_{0}+\alpha_{1} \Delta D D_{i t}+\alpha_{2} \Delta n f a_{i t}+\beta_{1} e r f_{i t}+\beta_{2} m b f_{i t}+\beta_{3} e c_{i t}+\sum_{j=1}^{m} \gamma_{j} X_{j, i t}+u_{i t}$.

$\Delta D D_{i t}\left(\Delta L D_{i t}\right)$ denotes the change in DD (LD) in country $i$ at time $t$, erf represents the exchange rate factor, $m b f$ stands for the money base factor, ec describes the errorcorrection term related to the size of desired dollarization, $\Delta n f a$ denotes the change in banks' net foreign assets, and $X_{j, i t}$ includes a list of control variables that are commonly found to explain a substantial variation in both DD and LD. ${ }^{2}$ In the baseline model, these are the interest rate differential (Basso et al. 2007), the minimum variance portfolio (mvp) dollarization share (Ize and Levy-Yeyati 2003), the change in the rate of inflation, an index of asymmetry of exchange rate movements (Rennhack and Nozaki 2006), and an index of exchange rate intervention (Barajas and Morales 2003). Finally, $\varepsilon_{i t}$ and $u_{i t}$ correspond to the error terms. As we examine the short-run determinants of both DD and $\mathrm{LD}$, the variables erf, $m b f, e c$, interest rate differential, and mvp differ in equations (1) and (2) to account for this distinction. The three last variables included in the $X$ matrix are common in both equations.

The changes in DD (LD) are measured by the first difference of foreign currency denominated deposits (loans) to total deposits (loans) of residents held in (issued by) resident banks. We include changes in DD as an explanatory variable of changes in LD to account for the short-run matching behavior of banks' foreign currency position. We expect, as already found in the long-run by Luca and Petrova (2008) and Barajas and Morales (2003), banks to limit their exchange rate risk by shifting it to borrowers and lend in foreign currency. Therefore, DD is expected to promote LD in the short-run. We also include the change in banks' net foreign assets in the $\triangle \mathrm{LD}$ specification since banks may match the level of overall assets and liabilities by currency. This implies that banks may substitute foreign currency loans to domestic borrowers with foreign assets, so that for a given level of foreign currency deposits a short-run increase in $n f a$ is expected to decrease LD.

The variables erf, $m b f$, and $e c$ have all been first used by Honohan (2007) in the analysis of the short-run determinants of DD and deserve some further explanation. The

\footnotetext{
${ }^{2}$ With regard to the determinants of short-run LD, we consider the findings of Luca and Petrova (2008) which provide strong evidence of the significance of the supply-side variables driven by the behavior of banks ( $\triangle D D$ and $\triangle n f a$ ) rather than the demand-side variables.
} 
exchange rate factor, using Honohan's (2007) terminology, captures the direct (or mechanical) effect of depreciation on DD, while the money base factor considers the impact effect of changes in the local-currency monetary base on DD. Both these immediate effects are due to the agent's portfolio rebalancing decisions against currencyrelated risk. This means that erf is expected to have an enhancing effect on DD, while $m b f$ a retarding effect. To save space, the derivation of both direct effects is provided in Appendix I.

Honohan (2007) also considers a more longer-lasting effect of depreciation, as it may affect the desired (or optimal) dollarization share of agents due to changes in their expectations about the long-term path of the exchange rate. Local currency depreciation may lead agents to revise their expectations toward future currency depreciation, and this expectation effect could reinforce the direct effect. ${ }^{3}$ We, as Honohan (2007), accommodate for this indirect effect of depreciation by modelling the desired dollarization share $F D^{*}$ with time trends (quadratic, cubic, etc) to capture the general long-run trend of FD. We then, create an error correction term, $e c_{i t}=F D_{i t}^{*}-F D_{i t-l}$, that allows deviations from the desired dollarization ratio to be closed over time. ${ }^{4}$ The speed of adjustment is measured by the parameter $\beta_{3}$ and a positive coefficient indicates convergence after shocks.

The variables included in the $X$ matrix are relatively straightforward. The interest rate differentials represent local currency minus foreign currency interest rates. If foreign currency interest rates offered by resident banks are unavailable, we use the interest rate offered by US banks. We expect interest rate differentials to have a negative (positive) effect on changes in DD (LD). As most studies find mvp dollarization to be a significant determinant of FD, we include this variable in our analysis. However, we compute it in an alternative way to the one proposed by Ize and Levy-Yeyati (2003) to better capture the importance of the relative conditional volatility of inflation against the conditional

\footnotetext{
3 Of course, this long-term effect is conditional on interest rate differentials which could move endogenously to offset any changes in desired dollarization. To account for this, we control for interest rate differentials.

${ }^{4}$ We allow for values of $l=1,2,3,6,12$ to consider a variety in the lag structure of the adjustment process toward the desired dollarization share. The benchmark value of the lag is $l=2$. We have also included separately the two parameters $F D_{t}^{*}$ and $F D_{i t-l}$ and found them to be statistically equivalent in size but of opposite signs. This justifies their joint consideration through the error correction term.
} 
volatility of nominal depreciation. The details of the computation and the associated explanation are provided in Appendix II. If significant, this variable is expected to positively affect changes in both DD and LD.

The change in the rate of inflation is included to account for potential effects of the current macroeconomic environment as illustrated by Savastano (1996) and Uribe (1997) in models of currency substitution. It is calculated as the first difference of the logarithmic difference of the CPI and is expected to have a positive effect on changes in both DD and LD. We also consider the asymmetry of exchange rate movements by constructing an index of bias in exchange rate policy. The index takes a value of -1 in months of currency appreciation and 1 in months of currency depreciation - when the exchange rate does not change we assign a value of 0 . Higher values of the index induce agents to hold more foreign currency assets and increase FD. Finally, we use an index of central bank exchange rate intervention to control for different exchange rate regimes. As indicated by Barajas and Morales (2003) pegged exchange rate regimes are expected to encourage FD as agents consider themselves immune to exchange rate fluctuations as authorities defend the peg. With higher values representing a harder peg, the index is associated with both higher DD and LD. A full description of all variables involved in the analysis and their related sources appear in Table A2, Appendix III.

Apart from examining the significance of the abovementioned variables in the short-run process of FD, the main contribution of this study deals with the extent to which the short-run impact of erf, $m b f$, and $\Delta n f a$ depends on the level of dollarization. This implies that our focus is on the coefficients of interaction terms between a highdollarization dummy and the erf, $m b f$, and $\triangle n f a$, respectively, for both DD and LD. In this way, the analysis can reveal to us the potentially different actions taken by individual depositors and banking institutions alike in high-dollarization countries. These actions would, in turn, depend on the options depositors and banks have in diversifying risk in their asset portfolios. This means that the regression specifications are now extended to

$$
\begin{aligned}
\Delta D D_{i t}= & \alpha_{0}+\delta_{1} H D_{i t}+\beta_{1} e r f_{i t}+\delta_{2} e r f_{i t} * H D_{i t}+\beta_{2} m b f_{i t}+\delta_{3} m b f_{i t} * H D_{i t}+\beta_{3} e c_{i t} \\
& +\sum_{j=1}^{m} \gamma_{j} X_{j, i t}+\varepsilon_{i t},
\end{aligned}
$$




$$
\begin{aligned}
\Delta L D_{i t}= & \alpha_{0}+\delta_{1} H D_{i t}+\alpha_{1} \Delta D D_{i t}+\alpha_{2} \Delta n f a_{i t}+\delta_{2} \Delta n f a_{i t} * H D_{i t}+\beta_{1} \operatorname{erf}_{i t}+\delta_{3} \operatorname{erf}_{i t} * H D_{i t} \\
& +\beta_{2} m b f_{i t}+\delta_{4} m b f_{i t} * H D_{i t}+\beta_{3} e c_{i t}+\sum_{j=1}^{m} \gamma_{j} X_{j, i t}+u_{i t},
\end{aligned}
$$

where $H D_{i t}$ denotes the high-FD dummy. As Honohan (2007), we first consider as highly dollarized countries those with DD and LD ratios in excess of 50 percent. ${ }^{5}$ Significance of the $\delta_{k}$ coefficients $(k=1, \ldots, 4)$ in both equations (3) and (4) would highlight that agents on both sides of the dollarization process (individuals and banks) respond symmetrically to increases in the level of dollarization. Significance of the $\delta_{k}$ coefficients, on the other hand, in just one of equations (3) and (4) would support an asymmetric optimal portfolio allocation behavior. We hypothesize that the $\delta_{k}$ coefficients are significant only in the short-run DD process in equation (3), reflecting the greater risk-aversion of depositors compared to banks in highly dollarized environments due to their fewer options in diversifying risk in their asset portfolios. We take this as evidence of the greater accessibility of banks to foreign financial markets and portfolio instruments compared to individual depositors. ${ }^{6}$

The panel estimations we use consider a variety of techniques. We first estimate equations (1) to (4) with pooled OLS with robust standard errors adjusted for heteroskedasticity and serial correlation. We next consider the random effects estimator and control for unobserved country-specific effects using the fixed effects estimator. In both cases we report robust standard errors adjusted for arbitrary serial correlation and heteroskedasticity. An additional way to correct for serial correlation in the errors is to assume that the errors follow an AR(1) process. We therefore estimate parametric models with the fixed and random effects GLS estimators that allow for AR(1) structure of the error term. For robustness, we also estimate the models with FGLS with panel heteroskedasticity and panel specific autocorrelation with $\mathrm{AR}(1)$ disturbances. Finally, we use a technique that addresses the potential endogeneity of the right-hand-side variables (in particular, the possibility that changes in the exchange rate and the monetary

\footnotetext{
${ }^{5} \mathrm{We}$ also test the significance of the results by altering the threshold to the sample mean and median (Levy-Yeyati 2006), at the 40 percent level (Rennhack and Nozaki 2006), and at the top quartile (Honohan 2007).

${ }^{6}$ At a later stage, we account explicitly for the effects of international financial integration on short-run DD and LD with an index constructed by Lane and Milesi-Ferretti (2007). In line with our postulation we find this variable to be a significant determinant only of LD.
} 
base along with interest rate differentials, as monetary policy instruments, may be influenced by FD). For this purpose, we use a standard 2SLS estimation where the instruments are the once lagged values of the variables. We also utilize both fixed and random effects 2SLS estimations with robust standard errors adjusted for heteroskedasticity and serial correlation. ${ }^{7}$

\subsection{Data}

We use an unbalanced panel dataset of monthly observations for 11 transition economies. We have restricted our attention to the transition economies with the longest period coverage of both DD and LD to allow a consistent treatment of their patterns of FD. A list of the countries and the related period coverage for each of DD and LD appear in Appendix III, Table A1 and have been mostly collected from national central bank reports. As Table A1 reveals, the sample period varies from one country to the other with the earliest period being 1993:2 (Ukraine) and the latest 2006:12 (Russia). ${ }^{8}$

Figure 1 shows the extent of both types of dollarization in the domestic banking system of the countries under consideration. Some important characteristics stand out. First, the degree of dollarization exhibits substantial variation across countries. There are countries like Armenia, Bulgaria, Georgia, and the Kyrgyz Rep., that have relatively high levels of both DD and FD, while countries like the Czech Rep. and Poland have low levels. Second, for some countries, Estonia, post-2001 Latvia, and Romania, there is a notable mismatch between the levels of foreign currency deposits and loans in favor of the latter.

These facts are more transparent in Table 1a which also indicates differences in the variability of dollarization over time, with Georgia exhibiting the highest variability in DD and Estonia in LD. In addition, it is clear that although most of the countries are characterized by highly positive correlations between DD and LD there are two

\footnotetext{
${ }^{7} \mathrm{We}$ have also used a system-GMM estimation technique which has been deemed to be superior to 2SLS. Unfortunately, the results were meaningless given that this technique has been developed for datasets with a large number of cross-sections and a small number of observations per cross-section, unlike our dataset. For this reason, we do not report the findings.

${ }^{8}$ We have also experimented by using a post-1996 sample period to restrict the effects of the early transition outliers. As shown later, the results are insensitive to this consideration.
} 
exceptions, Latvia and Poland, the latter experiencing a strong negative correlation. Finally, the sample average DD of 39.3 percent falls behind the average LD by about 9 percentage points. These figures coincide with those reported by Luca and Petrova (2008) and Basso et al. (2007), who use panels of a larger number of transition economies. For the entire sample, we also observe a strong positive correlation between the DD and LD of 71.2 percent, an outcome also illustrated in Figure 2. ${ }^{9}$ The fact, however, that DD and LD seem to mirror each other should not be taken as an indication that the one can be used as a proxy for the other - as considered, for instance, by Levy-Yeyati (2006). This consideration could mask potential different effects of some variables on the two types of dollarization, especially at the rank of highly dollarized economies. This is the line of argument we pursue in the formal analysis of the following sections.

The last two figures, $3 a$ and $3 b$, illustrate the time trends of DD and LD that correspond to the level of the desired dollarization share $F D^{*}$ as described earlier. Finally, Table $1 \mathrm{~b}$ presents summary statistics of all the variables involved in regression equations (1) to (4), plus a few additional variables that are used in the sensitivity analysis.

\section{Empirical Findings}

We begin our investigation by estimating the benchmark and extended equations (1) and (3) for the short-run determinants of DD with OLS, FE, RE, and FGLS using the set of control variables described above. We then follow a similar structure of estimations for equations (2) and (4) to examine the short-run determinants of LD.

\subsection{Deposit Dollarization}

The results of the baseline equation (1) are presented in Table 2. All six columns verify the main findings of Honohan (2007) with regard to the effects of the exchange rate factor, the money base factor, and the error correction on short-run DD in transition economies. A depreciation of the local currency induces depositors to switch the currency

\footnotetext{
${ }^{9}$ As evident in Table 1a, the outlier in Figure 2 is Estonia.
} 
composition of their deposits toward foreign currencies, while a monetary expansion of the local currency promotes local-currency deposits. Note, however, that the quantitative effect of the erf far exceeds that of the $m b f$ implying the relative significance of the former. In addition, the error correction term highlights the process of convergence after shocks as depositors adjust their currency portfolio in accordance to their desired dollarization share. The results also offer support to the negative impact of the deposits interest rate differential on short-run DD. That is, as the local-currency interest rate rises compared to the foreign-currency counterpart, short-run DD declines. This result is in line with the theoretical model and the empirical findings of Basso et al. (2007) in a set of transition economies and with Arteta (2005) in the examination of long-run DD. All the above variables are significant at the highest confidence level and their magnitude remains insensitive to the different regression techniques.

The mvp dollarization share does not appear to significantly impact upon shortrun DD, as also established by Basso et al. (2007). It seems that mvp's effect on DD is materializing only in the long-run as agents have the capacity to better assess the differences associated with the volatility of inflation versus that of depreciation, as supported by a number of studies (Ize and Levy-Yeyati 2003; De Nicoló et al. 2003; Rennhack and Nozaki 2006). Also changes in the rate of inflation do not seem to affect short-run DD in the majority of the regressions. ${ }^{10}$ This finding supports the evidence of the weak link between inflation and currency substitution of savings in the long-run (Levy-Yeyati 2006). This effect does not change, in a later section, even when we consider the maximum historical rate of inflation to allow for possible hysteresis effects. A variable that captures the asymmetry of exchange rate policy, as first introduced by Rennhack and Nozaki (2006), has no effect on short-run DD. Depositors appear to respond symmetrically to upward and downward changes in the exchange rate with no indication of a bias toward local-currency depreciation. Finally, the degree of exchange rate intervention by the monetary authorities, as captured by the constructed index, has no explanatory power on short-run DD. This means that greater central bank intervention, representing a less flexible exchange rate regime, is not associated with more $\mathrm{DD}$, as also found by Rennhack and Nozaki (2006) and Basso et al. (2007).

\footnotetext{
${ }^{10}$ An exception is column (6) which indicates a positive effect.
} 
The next step of the analysis is to examine the sensitivity of the short-run determinants of DD to the degree of DD. With this in mind, Table 3 reports the estimation results of equation (3) that accounts for interaction terms between a highdollarization dummy and erf and $m b f$. Before discussing these results in detail, we note that our main conjecture is strongly supported in each case. The coefficients on the interaction terms are highly significant across all regressions highlighting the stronger response of depositors in the events of depreciation and local-currency monetary growth in highly-dollarized environments. Thus, both local-currency depreciation and monetary expansion appear to have a more severe effect on short-run DD in countries characterized by high levels of dollarization. Also, note that the impact of the rest of the explanatory variables remains unchanged to the introduction of the high-dollarization dummy and the interaction terms, the only exception now being the statistical significance of the index of asymmetry.

The consideration of the high-dollarization dummy, which represents ratios of DD exceeding 50 percent, improves the fit of the model in all six columns. The strong significance of the dummy illustrates the greater bias of depositors in highly-dollarized countries to keep foreign-currency denominated deposits. This bias is further reinforced in the event of local-currency depreciations as shown by the significance of the multiplicative term between the dummy and erf. This translates to a greater sensitivity of depositors against depreciations in highly-dollarized environments. So, even though on average the estimated within-month impact of depreciation on the portfolio of deposits is to cause a re-denomination of the currency of deposits of about 70 percent, the magnitude increases to the theoretical impact of 100 percent in highly-dollarized countries. That is, depositors in countries that experience high-dollarization fully rebalance the composition of their deposits in light of depreciation. To determine statistically the magnitude of erf in countries with high DD we have performed a significance test (see Table 3), which provides strong support to our claim.

The extended results also indicate that, on average, the money base factor has no significant explanatory power on short-run DD. It is rather the impact of monetary expansion in high-dollarized countries that diminishes the holdings of foreign currency deposits. The estimations imply that about 40 percent of the depositors' portfolio is 
rebalanced toward more local-currency deposits in the event of a monetary expansion in highly-dollarized countries. Again, as in the baseline case, we observe the average quantitative effect of depreciation to exceed the effect of monetary expansion which is

even now more pronounced in highly-dollarized countries. Finally, the effect of an asymmetric exchange rate policy biased toward local-currency depreciation also appears to decrease short-run DD. This result is, however, counterintuitive as such an asymmetric policy is expected to lead depositors to hold more foreign currency in the portfolios, especially if combined with limited exchange rate flexibility. Note however that this result is not robust to different specifications and the estimated size of the effect on the $\triangle \mathrm{DD}$ is trivial.

\subsection{Loan Dollarization}

We now turn to the examination of the short-run determinants of LD as these are captured in equations (2) and (4). The findings of both of these specifications appear in Table 4, which utilizes a FE estimation although the results are robust to the other estimations techniques as well. Column (1) estimates a specification similar to equation (1) of DD. That is, it does not take into account the potential impact of changes in banks' net foreign assets. The results are comparable to the ones outlined in Table 1. Specifically, both the exchange rate and the money base factors significantly impact upon short-run LD with a depreciation inducing banks to raise foreign currency loans and a monetary expansion to diminish it. These optimal responses of banks to changes in the value of the local currency match those of depositors and is a first sign of banks' currency matching behavior that tend to shift exchange rate risk to borrowers.

As for the rest of the explanatory variables of short-run LD, they also do not deviate from the findings with regard to DD. In particular, we observe that the error correction term signifies convergence toward the desired dollarization share of banks in the presence of deviations, the interest rate differential has, as expected, a positive effect, while the mvp, the change in the rate of inflation, and the index of central bank intervention have no significant explanatory impact. Finally, the index of asymmetric exchange rate policy indicates a small negative effect. 
Moving to column (2), which adds the effect of changes in banks' net foreign assets, we obtain the expected outcome of a negative influence in changes in LD. An increase in net foreign assets is associated with a lower supply of foreign currency loans by banks. This represents an indication of banks' greater possibility of diversification of their assets. The next column adds the change in DD as an explanatory variable to explicitly capture the aversion of banks' toward mismatching of their foreign currency deposits and loans. The strong positive coefficient emphasizes banks' desire to maintain matched positions in the short-run. This result complements well the long-run evidence of banks' matching behavior as illustrated by Barajas and Morales (2003) and, more recently, Luca and Petrova (2008).

Column (4) tests the importance of the high-dollarization dummy and its interaction effects with erf, $m b f$, and $\Delta n f a$. In contrast to the case of deposit dollarization, however, none of these variables are now significant for short-run loan dollarization. This finding supports the notion that banks do not operate differently as to their reaction in changes in the exchange rate, the monetary base, or net foreign assets in highdollarization environments. This contrasting behavior of banks and individuals, however, highlights an asymmetric optimal portfolio allocation of financial assets. Unlike individuals, banks have more options in diversifying risk as illustrated by the negative effect of net foreign assets. Therefore, they are not under pressure to loan more foreign currencies in highly-dollarized environments because they can hold more foreign assets, an option not necessarily available to individuals.

To further explore this issue, we include in the parsimonious model in column (5) an index of international financial integration (see Lane and Milesi-Ferretti 2007). Although not significant in Table 4, it is highly significant in most of the alternative regression techniques in Table 5. This additional negative effect of financial integration on short-run LD independently of the negative effect of changes in net foreign assets, reinforces the conjecture that a more financially integrated economy increases banks' likelihood to substitute further foreign assets for foreign credit. In the next section, we also include the index of financial integration in the deposit dollarization equation to examine whether it represents a true alternative to depositors. 


\section{Robustness Tests}

We examine the sensitivity of our results by conducting the following exercises. First, we consider the possible endogeneity of explanatory variables. Second, we modify the definitions of the high-dollarization dummy, the minimum variance portfolio, and the error correction term. Third, we allow for a different sample period. Fourth, we control for additional right-hand-side variables, and, finally, briefly discuss some additional sensitivity checks.

Our estimations have so far been based on the assumption that all explanatory variables are exogenous to changes in dollarization. To address the issue of endogeneity we use a 2SLS estimation technique that uses as instruments one-period lagged values, where at the same time we control for fixed and random effects. Columns (1) and (2) of Table 6 control for the endogeneity (indicated by bold type) of the interest rate differential, the change in inflation rate, and the index of asymmetry in the DD equation. The following two columns expand the instrumented set to the erf, the $m b f$, and their interactions with the high-dollarization dummy. In all cases, the instrumentation strategy has no qualitative effect on the findings. We still observe that high-dollarization makes a difference to the behavior of depositors, especially in the events of local-currency depreciation and monetary expansion. Instrumentation of the LD equation also carries no significant difference to our main results, as illustrated by the last two columns of Table 5. We now also see the exchange rate factor increasing to one, implying that on average not just during high dollarization - banks fully re-denominate the currency portfolios of their loans in response to depreciation.

One could argue that the results are sensitive to the particular way we have defined some of the variables. Obvious candidates are the high-dollarization dummy, the error correction term, and the minimum variance portfolio dollarization. To this extent, we present in the first four columns of Table 7 and 8, for DD and LD respectively, fixed effects regressions that consider alternative definitions. ${ }^{11}$ Column (1) of both tables shows that even if we define the high-dollarization dummy to take the value of one for ratios in excess of 75 percent of $\mathrm{DD}$ and $\mathrm{LD}$, respectively, the results provide

\footnotetext{
${ }^{11}$ Note that, as the notes of the tables reveal, results are insensitive to different regression techniques.
} 
confirmation of our previous findings. As column (2) shows, the same applies if we define instead a three-range dollarization dummy that takes the value of zero for dollarization shares less than 25 percent, the value of one for shares between 25 and 50 percent, and the value of two for shares greater than 50 percent. Similarly, results remain unaltered to the use of an alternative definition for mvp (MVP2), as described in Appendix II. This is clearly illustrated in column (3), while column (4) shows that the results are robust to the computation of an error correction term that considers deviations from desired dollarization shares from six months ago. ${ }^{12}$

Column (5) takes into account the possibility that results are driven by the early abnormal experience of transition years where agents were favourable to foreign currency holdings due to involved uncertainty surrounding the success of market-oriented policies. For this reason, we limit the sample to the post-1996 period. The results are not affected by this data restriction.

Finally, we explore the validity of our findings to different specifications by including additional drivers of dollarization. These are considered in columns (6) and (7). Following De Nicolo et al. (2003) and Levy-Yeyati (2006), column (6) includes a measure of institutional quality. Both of these studies have found that a lower quality of institutions enhances long-run deposit dollarization to the effect that institutions proxy for the credibility of monetary policy. Although the estimated coefficient of institutions, as measured by the ICRG index of corruption has the correct sign, it is not a significant determinant of short-run deposit dollarization. ${ }^{13}$ On the contrary, as Table 8 shows, lower corruption does impact on short-run loan dollarization in a negative way - even though the size of the effect is relatively small. Thus, the predictive power of institutions on long-run dollarization is confirmed in the short-run only for the credit counterpart of dollarization. ${ }^{14}$

Column (7) expands the list of additional right-hand-side variables to include the maximum historical inflation and depreciation rates, a dummy for European Union

\footnotetext{
${ }^{12}$ The findings do not change even if we consider a lag structure of deviations of 1,3 , or 12 months.

${ }^{13}$ Note that a higher value of the corruption index, which ranges from 0 to 6 , implies a lower level of corruption. Thus, as the corruption index rises, the institutional view of dollarization predicts a lower level of foreign currency deposits.

${ }^{14}$ Of course, the statistically diverse effect of corruption on DD versus LD could be an implication of the restricted dataset. However, a second indicator of corruption from Transparency International (CPI) which covers a longer time period in our dataset produces qualitatively similar results.
} 
membership, international financial integration (for the case of DD), and a dummy to capture the immediate aftermath of the Russian crisis. Although Arteta (2005) has shown both the maximum historical rates of inflation and depreciation to boost long-run deposit and credit dollarization, we only find supporting evidence for the increasing effect of maximum depreciation on short-run LD. ${ }^{15}$ We also confirm the findings of Levy-Yeyati (2006) and Rosenberg and Tirpák (2008) as to the statistically insignificant effect of imminent euro adoption on both DD and LD, as captured by the EU membership dummy. Joining the EU is considered to promote FD through increased trade and financial links, a growing convergence of exchange rates to the euro, and the anticipation of official adoption of the euro. However, these factors do not appear to affect dollarization in the short-run. A potential explanation could be that all these effects come into play before the actual entry date, and are, therefore, not properly captured by the EU dummy. We do account for this with two additional dummies that highlight the beginning of the accession process and the decision to join (see Appendix III, Table A2 for description). None of these two dummies adds explanatory power since they are found to be insignificant (not shown in tables; available upon request).

The final two extra variables we control for are a dummy for the Russian crisis and the index of financial integration. Although studies like Basso et al. (2007) consider post-2000 data to avoid problems related to the Russian crisis, our findings show that the Russian crisis has no significant effect on either side of short-run dollarization. As it regards financial integration, recall that it has already been found to decrease loan dollarization, a result also evident in column (7) of Table 8. Table 7, however, shows that financial integration has no discernible effect on deposit dollarization. This result points to the limited access of individuals to the international financial market as a way of diversifying their portfolios compared to banks that are directly involved in it.

Last, we confirm our main findings using additional sensitivity tests. First, we estimate the extended deposit dollarization model equation (3) by considering three dummies of dollarization that correspond to three regions of DD: low, medium, and

${ }^{15}$ The maximum historical rate of inflation is only significant at the 90 percent confidence level. 
high. ${ }^{16}$ Second, we confirm that our findings are not driven by outliers as we re-run the regressions dropping one country at a time. Finally, we control for a dummy (restrictions) that measures the liberalization of residents' holdings of onshore foreign currency deposits. As in Luca and Petrova (2008) we find restrictions on residents' foreign currency accounts not to have a significant effect on short-run DD.

With regard to the first additional test, we follow Rioja and Vanev (2004) and create the low region DD dummy such that is equal to 1 if DD is below a certain lower threshold and 0 otherwise. Similarly, the high region DD dummy equals 1 if DD is greater than a certain upper threshold and 0 otherwise. Next, these dummies are interacted with erf and $m b f$ to examine their increasing significance in highly-dollarized environments. Given that the thresholds are not known a priori, the model is estimated repeatedly varying the thresholds over a wide range. The lower threshold is alternatively placed at the $10^{\text {th }}, 15^{\text {th }}, 20^{\text {th }}, \ldots$, and $45^{\text {th }}$ percentiles of the distribution of DD, while the upper threshold is placed at the $55^{\text {th }}, 60^{\text {th }}, \ldots$, and $90^{\text {th }}$ percentiles. Each low threshold is paired with every high threshold, generating a total of 64 regressions. We, however, report nine sets of results in Table 9 that are representative of the general trend. The estimates for both erf and $m b f$ confirm our earlier findings. The effect of erf is significant in most of the three regions of DD increasing in magnitude for higher DD, and becoming equal to one for the high region. The effect of $m b f$, on the other hand, is statistically equal to zero for the low region and typically significant only in the high region. It is worth noting the consistency in the size of the effects for all nine combinations.

\section{Conclusions}

Depositors and financial institutions in transition economies hold deposits and issue loans, respectively, in foreign currencies as a way of minimizing their portfolio risk as they shield themselves against exchange rate fluctuations and seek for the highest expected rates of asset return. The behavior of the two types of agents may be driven, however, by different forces as these are reflected by the different set of options available

\footnotetext{
${ }^{16}$ A similar test is not conducted for loan dollarization given the insignificance of the high-dollarization related terms in Table 4.
} 
to them. To shed light on this issue, this paper examines the practice of foreign currencydenominated deposits by depositors and loans by banks in transition economies from a short-run perspective. In this respect, we identify the short-run determinants of deposit and loan dollarization and show that their impact varies with regard to the existing degree of dollarization.

The evidence presented suggests the following results. First, the positive (negative) short-run effects of depreciation (monetary expansion) on deposit dollarization are exacerbated in countries with high dollarization, while such a phenomenon is absent in the case of loan dollarization. This asymmetry in the behavior of asset allocation between depositors and banks in highly dollarized environments can be conceived to imply the limited alternatives available to depositors compared to banks which have more options in diversifying portfolio risk. Second, short-run loan dollarization is mainly driven by banks matching of domestic loans and deposits (as these are also captured by changes in the exchange rate and the monetary base) and currency matching of assets and liabilities. As in the long-run analyses of Barajas and Morales (2003) and Luca and Petrova (2008), banks are also found in the short-run to transfer the currency risk of their foreign currency liabilities onto firms by lending. Third, short-run loan dollarization is also, but to a smaller extent, influenced by international financial integration and institutional quality, and finally, both short-run deposit and loan dollarization are affected by interest rate differentials and deviations from desired dollarization.

These results indicate the presence of common factors in driving the process of both types of dollarization in the short-run. At the same time, however, they highlight that these two processes are independently influenced by different factors. Most importantly, they also make clear of the different impact of some factors on deposit versus loan dollarization in economies characterized by high levels of dollarization. These findings suggest that the short-term analysis of dollarization should jointly consider the examination of both sides of banks' balance sheets without neglecting the potentially distinct outcomes in high-dollarized environments. 


\section{References}

Arteta, C.Ó., 2005. Exchange rate regimes and financial dollarization: Does flexibility reduce bank currency mismatches? B.E. Topics in Macroeconomics 5(1), 1226-1226.

Barajas, A., Morales, R.A., 2003. Dollarization of liabilities: Beyond the usual suspects. IMF Working Paper 03/11.

Basso, H.S., Calvo-Gonzalez, O., and Jurgilas, M., 2007. Financial dollarization: The role of banks and interest rates. ECB Working Paper 748.

Billmeier, A., Bonato, L., 2004. Exchange rate pass-through and monetary policy in Croatia. Journal of Comparative Economics 32, 426-444.

Bollerslev, T., 1986. Generalized autoregressive conditional heteroskedasticity. Journal of Econometrics 31, 307-327.

Catão, L., Terrones, M., 2000. Determinants of dollarization: The banking side. IMF Working Paper 00/146.

Choudhry, T., 2005. Exchange rate volatility and the United States exports: Evidence from Canada and Japan. Journal of Japanese International Economies 19, 51-71.

De Nicoló, G., Honohan, P., and Ize, A., 2003. Dollarization of the banking system: Good or bad? IMF Working Paper 03/146.

Engle, R., 2002. Dynamic Conditional Correlation: A Simple Class of Multivariate Generalized Autoregressive Conditional Heteroskedasticity Models. Journal of Business and Economic Statistics 20, 339-350.

Fornari, F., Mele, A., 1997. Asymmetries and non-linearities in economic activity. Applied Financial Economics 7, 203-206.

Grier, K., Perry, M., 2000. The effects of uncertainty on macroeconomic performance: bivariate GARCH evidence. Journal of Applied Econometrics 15, 45-58.

Honohan, P., 2007. Dollarization and exchange rate fluctuations. CEPR Discussion Paper 6205.

Ize, A., Levy-Yeyati, E., 2003. Financial dollarization. Journal of International Economics 59, 323-347.

Lane, P.R., Milesi-Ferretti, G.M., 2007. The external wealth of nations mark II: Revised and extended estimates of foreign assets and liabilities, 1970-2004. Journal of International Economics 73(2), 223-250. 
Levy-Yeyati, E., 2006. Financial dollarization: Evaluating the consequences. Economic Policy 61-118.

Luca, A., Petrova, I., 2008. What drives credit dollarization in transition economies? Journal of Banking and Finance 32(5), 858-869.

Rennhack, R., Nozaki, M., 2006. Financial dollarization in Latin America. IMF Working Paper 06/7.

Rioja, F., Vanev, N., 2004. Does one size fit all? A re-examination of the finance and growth relationship. Journal of Development Economics 74, 429-447.

Rosenberg, C.B., Tirpák, M., 2008. Determinants of foreign currency borrowing in the new member states of the EU. IMF Working Paper 08/173.

Sahay, R., Vegh, C.A., 1996. Dollarization in transition economies: Evidence and policy implications. In: Mizen, P., Pentecost, E.J. (Eds.), The Macroeconomics of International Currencies: Theory, Policy, and Evidence, Cheltenham, UK, pp. 193224.

Savastano, M., 1996. Dollarization in Latin America: Recent evidence and some policy issues. IMF Working Paper 96/4.

Uribe, M., 1997. Hysteresis in a simple model of currency substitution. Journal of Monetary Economics 40, 185-202. 


\section{Figure 1: Financial Dollarization}
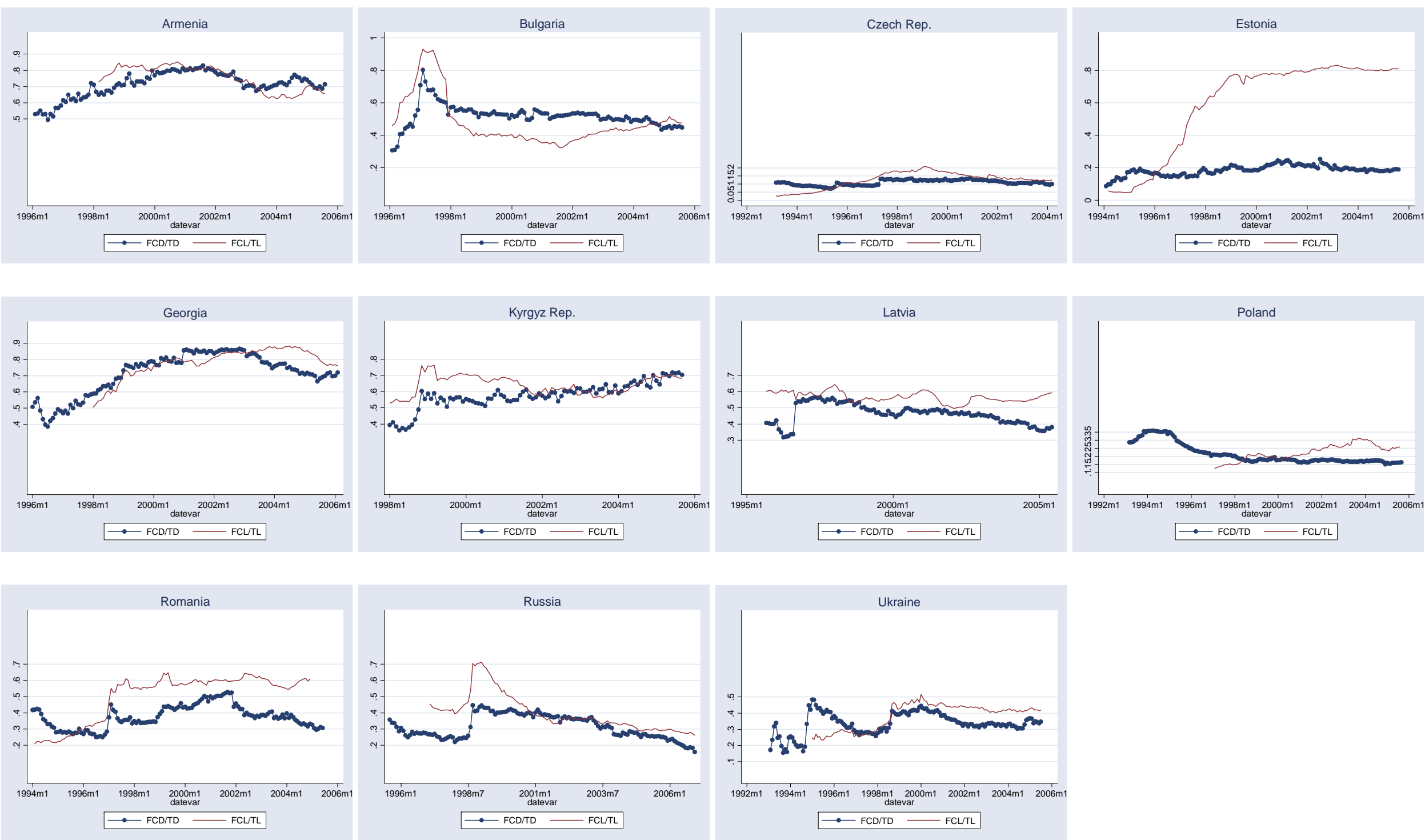
Figure 2: Deposit and Loan Dollarization (Country Averages)

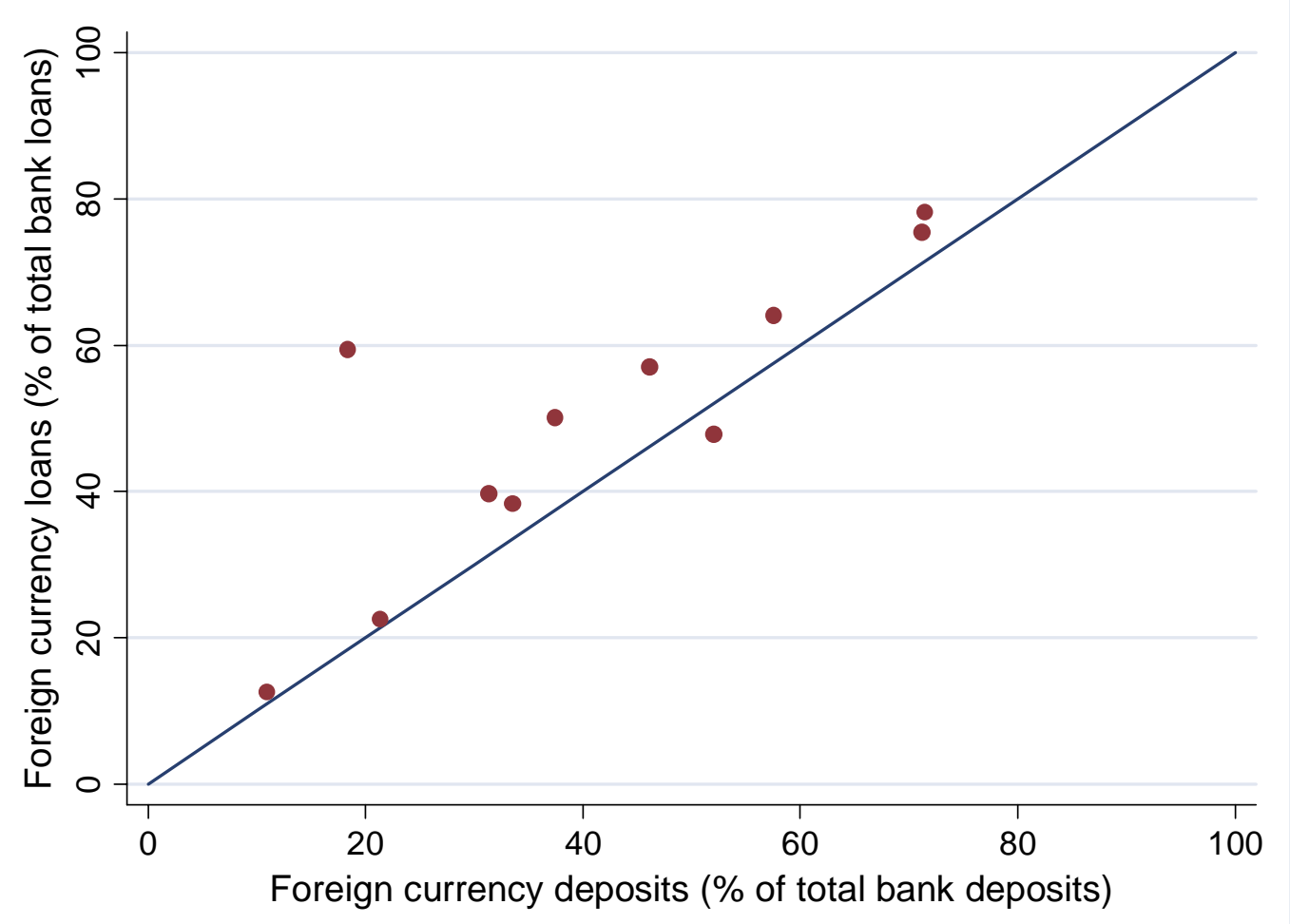


Figure 3a: Foreign Currency Deposits and Time Trend
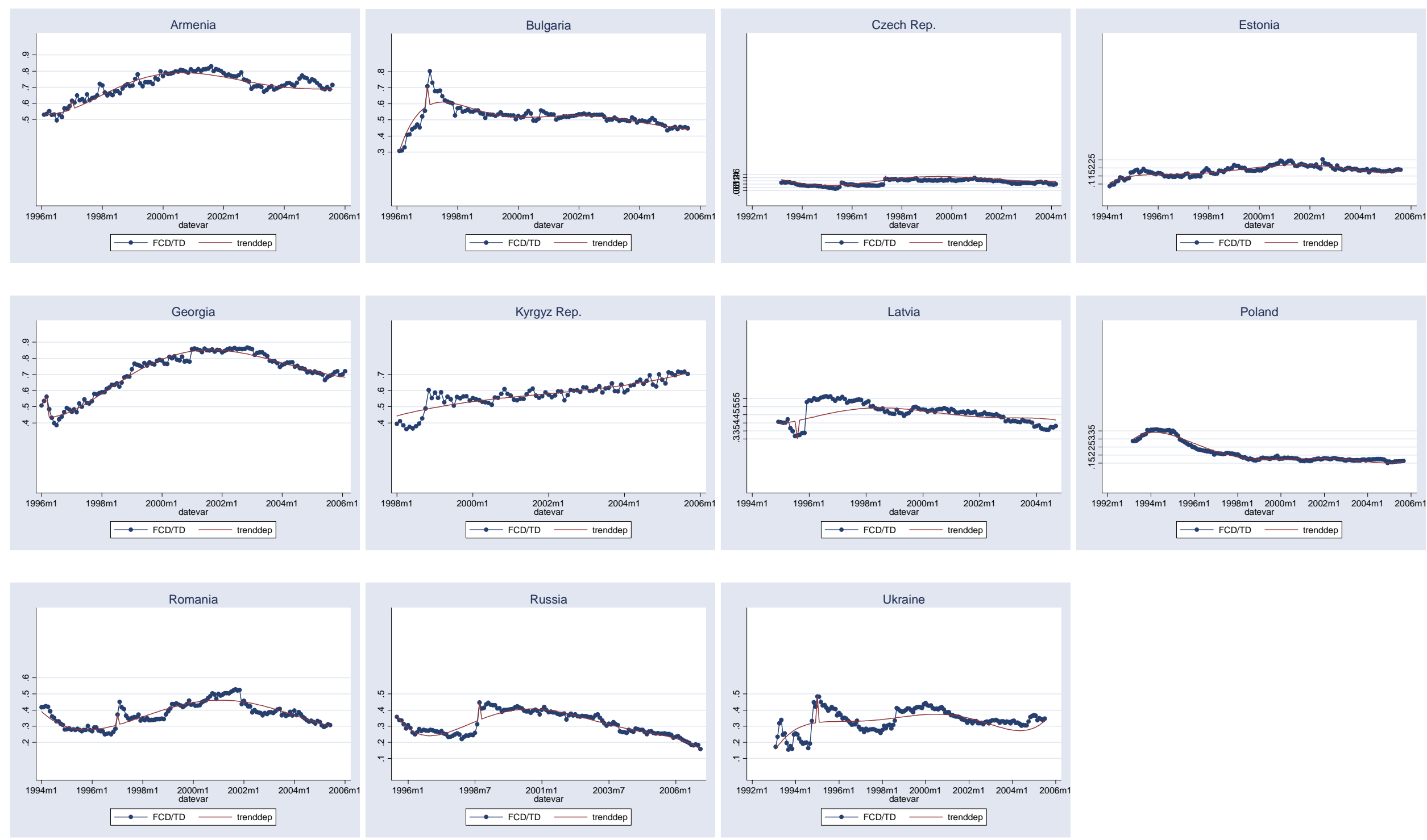
Figure 3b: Foreign Currency Loans and Time Trend
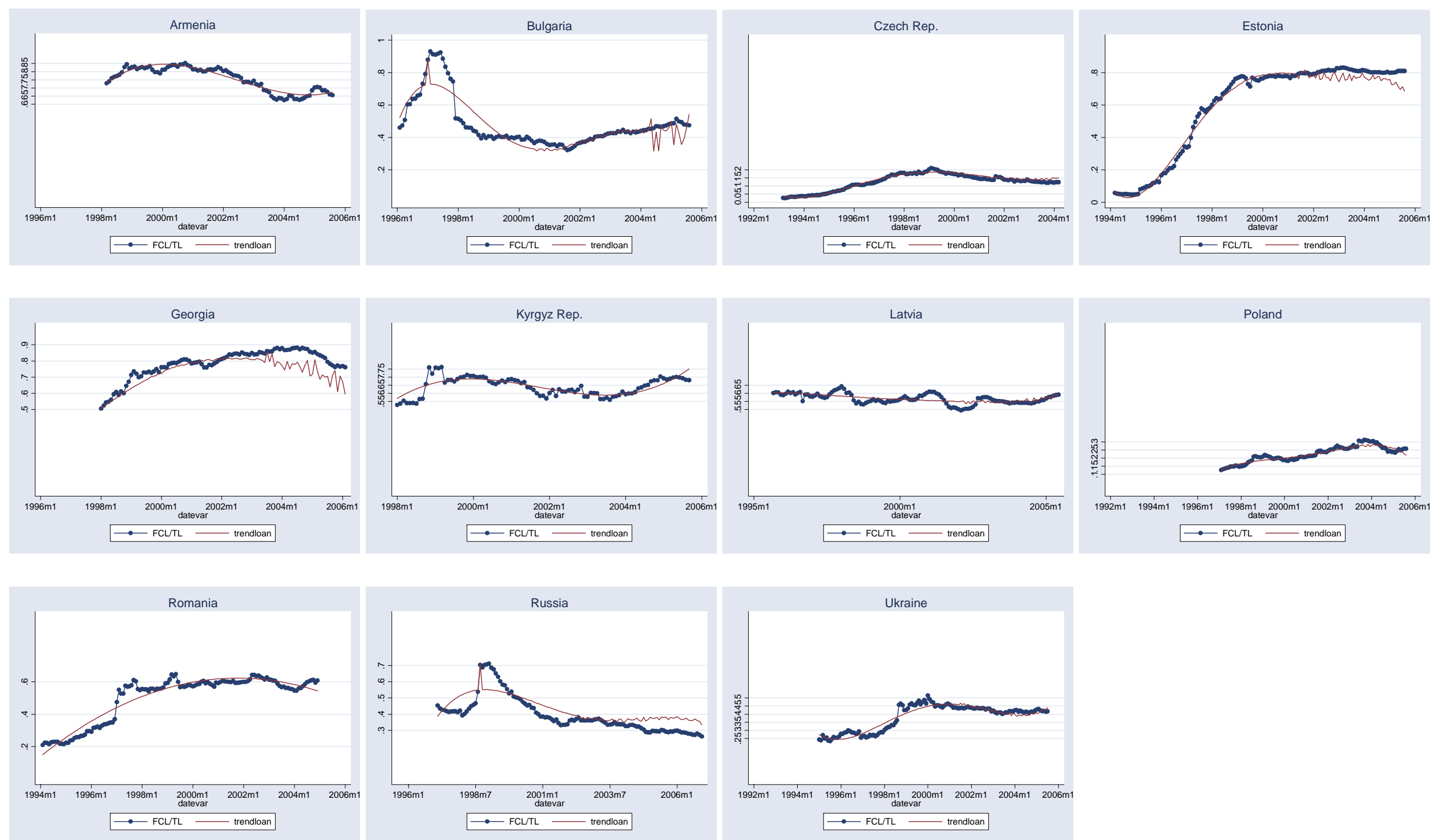
Table 1a: Summary Statistics and Correlations of Deposit and Loan Dollarization

\begin{tabular}{|c|c|c|c|c|c|c|c|c|c|c|c|c|}
\hline \multirow[b]{2}{*}{ Country } & \multicolumn{5}{|c|}{ Deposit Dollarization } & \multicolumn{5}{|c|}{ Loan Dollarization } & \multirow{2}{*}{$\begin{array}{l}\text { Differences } \\
\text { in Mean }\end{array}$} & \multirow[t]{2}{*}{ Correlation } \\
\hline & Obs & Mean & Std Dev & Min & Max & Obs & Mean & Std Dev & Min & Max & & \\
\hline Armenia & 115 & 71.17 & 7.82 & 49.54 & 82.90 & 90 & 75.49 & 7.40 & 62.49 & 85.36 & -4.32 & 0.5290 \\
\hline Bulgaria & 115 & 52.03 & 6.93 & 30.59 & 80.15 & 115 & 47.86 & 14.93 & 32.27 & 93.01 & 4.17 & 0.4914 \\
\hline Czech Rep. & 133 & 10.96 & 1.66 & 7.14 & 13.81 & 133 & 12.53 & 5.01 & 2.56 & 21.03 & -1.57 & 0.7476 \\
\hline Estonia & 139 & 18.40 & 3.06 & 8.63 & 25.20 & 138 & 59.46 & 28.37 & 4.60 & 83.05 & -41.06 & 0.7036 \\
\hline Georgia & 122 & 71.46 & 12.88 & 38.50 & 86.68 & 98 & 78.11 & 8.93 & 50.55 & 88.18 & -6.65 & 0.6159 \\
\hline Kyrgyz Rep. & 93 & 57.60 & 8.04 & 36.06 & 71.73 & 93 & 64.12 & 5.79 & 52.83 & 76.21 & -6.52 & 0.3982 \\
\hline Latvia & 118 & 46.13 & 6.20 & 31.84 & 56.44 & 118 & 56.99 & 3.35 & 49.50 & 64.30 & -10.86 & 0.0480 \\
\hline Poland & 151 & 21.39 & 6.29 & 15.13 & 35.82 & 103 & 22.47 & 4.79 & 12.60 & 31.23 & -1.08 & -0.6955 \\
\hline Romania & 138 & 37.46 & 7.15 & 24.99 & 52.73 & 131 & 50.15 & 14.40 & 20.87 & 64.77 & -12.69 & 0.6201 \\
\hline Russia & 137 & 31.36 & 7.19 & 15.82 & 44.63 & 119 & 39.70 & 11.12 & 26.18 & 71.09 & -8.34 & 0.6518 \\
\hline Ukraine & 150 & 33.56 & 6.82 & 15.46 & 48.33 & 127 & 38.26 & 7.98 & 23.35 & 51.45 & -4.7 & 0.2682 \\
\hline Total & 1410 & 39.30 & 20.62 & 7.14 & 86.68 & 1273 & 48.24 & 22.97 & 2.56 & 93.01 & -8.94 & 0.7122 \\
\hline
\end{tabular}

Sources: IMF, International Financial Statistics and National Central Banks. 
Table 1b: Summary Statistics of Variables

\begin{tabular}{|c|c|c|c|c|c|}
\hline Variable & Mean & Std Deviation & Min & Max & Obs \\
\hline \multicolumn{6}{|l|}{ Deposit Dollarization } \\
\hline Change in dollarization (\% of total deposits) & $0.047 \%$ & $1.9 \%$ & $-9.2 \%$ & $19 \%$ & 1399 \\
\hline Money base factor & $0.456 \%$ & $1.4 \%$ & $-10.3 \%$ & $10.2 \%$ & 1410 \\
\hline Error correction & $-0.023 \%$ & $3.5 \%$ & $-19.6 \%$ & $18.8 \%$ & 1410 \\
\hline \multicolumn{6}{|l|}{ Loan Dollarization } \\
\hline Change in dollarization ( $\%$ of total loans) & $0.138 \%$ & $1.6 \%$ & $-22.6 \%$ & $16.4 \%$ & 1262 \\
\hline Change in net foreign assets & $-0.122 \%$ & $4.5 \%$ & $-34.8 \%$ & $88.3 \%$ & 1399 \\
\hline Exchange rate factor & $0.175 \%$ & $1 \%$ & $-2.5 \%$ & $14.8 \%$ & 1273 \\
\hline \multicolumn{6}{|l|}{ Common Variables } \\
\hline Change in inflation rate & $-0.04 \%$ & $4.2 \%$ & $-11.5 \%$ & $8.32 \%$ & 1399 \\
\hline Index of asymmetry of exchange rate movements & 0.174 & 0.973 & -1 & 1 & 1419 \\
\hline Index of exchange rate intervention & 0.707 & 0.370 & 0 & 1 & 1410 \\
\hline Dummy for European Union membership & 0.026 & 0.159 & 0 & 1 & 1419 \\
\hline Index of international financial integration & 1.14 & 0.449 & 0.415 & 2.51 & 1305 \\
\hline Dummy for maximum inflation rate & 0.007 & 0.088 & 0 & 1 & 1410 \\
\hline Dummy for maximum depreciation rate & 0.007 & 0.088 & 0 & 1 & 1410 \\
\hline ICRG corruption index & 2.99 & 1.18 & 1 & 5 & 828 \\
\hline
\end{tabular}

Sources: IMF, International Financial Statistics, National Central Banks, the European Union, Lane and Milesi-Ferretti (2007), and the PRS Group. 
Table 2: Deposit Dollarization: Benchmark Model

\begin{tabular}{|c|c|c|c|c|c|c|}
\hline Variable & $\begin{array}{c}\text { OLS } \\
\text { (1) }\end{array}$ & $\begin{array}{l}\text { FE } \\
\text { (2) }\end{array}$ & $\begin{array}{l}\text { RE } \\
\text { (3) }\end{array}$ & $\begin{array}{c}\text { FE-AR(1) } \\
\text { (4) }\end{array}$ & $\begin{array}{c}\text { RE-AR(1) } \\
\text { (5) }\end{array}$ & $\begin{array}{c}\text { FGLS-PSAR(1) } \\
\text { (6) }\end{array}$ \\
\hline Exchange rate factor & $\begin{array}{c}0.741 \\
(0.000)\end{array}$ & $\begin{array}{c}0.742 \\
(0.000)\end{array}$ & $\begin{array}{c}0.742 \\
(0.000)\end{array}$ & $\begin{array}{c}0.791 \\
(0.000)\end{array}$ & $\begin{array}{c}0.763 \\
(0.000)\end{array}$ & $\begin{array}{c}0.688 \\
(0.000)\end{array}$ \\
\hline Money base factor & $\begin{array}{l}-0.124 \\
(0.337)\end{array}$ & $\begin{array}{l}-0.122 \\
(0.000)\end{array}$ & $\begin{array}{l}-0.123 \\
(0.000)\end{array}$ & $\begin{array}{l}-0.108 \\
(0.001)\end{array}$ & $\begin{array}{l}-0.112 \\
(0.000)\end{array}$ & $\begin{array}{l}-0.094 \\
(0.000)\end{array}$ \\
\hline Error correction & $\begin{array}{c}0.127 \\
(0.000)\end{array}$ & $\begin{array}{c}0.129 \\
(0.000)\end{array}$ & $\begin{array}{c}0.129 \\
(0.000)\end{array}$ & $\begin{array}{c}0.115 \\
(0.000)\end{array}$ & $\begin{array}{c}0.116 \\
(0.000)\end{array}$ & $\begin{array}{c}0.132 \\
(0.000)\end{array}$ \\
\hline Interest rate differential & $\begin{array}{l}-0.009 \\
(0.001)\end{array}$ & $\begin{array}{l}-0.009 \\
(0.000)\end{array}$ & $\begin{array}{l}-0.009 \\
(0.000)\end{array}$ & $\begin{array}{l}-0.009 \\
(0.000)\end{array}$ & $\begin{array}{l}-0.009 \\
(0.000)\end{array}$ & $\begin{array}{l}-0.008 \\
(0.000)\end{array}$ \\
\hline Minimum variance portfolio & $\begin{array}{c}0.000 \\
(0.975)\end{array}$ & $\begin{array}{l}-0.000 \\
(0.981)\end{array}$ & $\begin{array}{l}-0.000 \\
(0.999)\end{array}$ & $\begin{array}{c}0.000 \\
(0.911)\end{array}$ & $\begin{array}{c}0.000 \\
(0.901)\end{array}$ & $\begin{array}{c}0.000 \\
(0.903)\end{array}$ \\
\hline Change in inflation rate & $\begin{array}{c}0.014 \\
(0.109)\end{array}$ & $\begin{array}{c}0.014 \\
(0.178)\end{array}$ & $\begin{array}{c}0.014 \\
(0.174)\end{array}$ & $\begin{array}{c}0.008 \\
(0.395)\end{array}$ & $\begin{array}{c}0.011 \\
(0.242)\end{array}$ & $\begin{array}{c}0.024 \\
(0.010)\end{array}$ \\
\hline Asymmetry & $\begin{array}{l}-0.001 \\
(0.255)\end{array}$ & $\begin{array}{l}-0.001 \\
(0.149)\end{array}$ & $\begin{array}{l}-0.001 \\
(0.132)\end{array}$ & $\begin{array}{l}-0.001 \\
(0.238)\end{array}$ & $\begin{array}{l}-0.001 \\
(0.232)\end{array}$ & $\begin{array}{l}-0.001 \\
(0.002)\end{array}$ \\
\hline Intervention & $\begin{array}{c}0.001 \\
(0.690) \\
\end{array}$ & $\begin{array}{c}0.001 \\
(0.560) \\
\end{array}$ & $\begin{array}{c}0.001 \\
(0.616) \\
\end{array}$ & $\begin{array}{c}0.001 \\
(0.730) \\
\end{array}$ & $\begin{array}{c}0.001 \\
(0.830) \\
\end{array}$ & $\begin{array}{c}0.001 \\
(0.974)\end{array}$ \\
\hline $\begin{array}{l}\text { Countries / Obs } \\
\text { R-square }\end{array}$ & $\begin{array}{c}11 / 1395 \\
0.364\end{array}$ & $\begin{array}{c}11 / 1395 \\
0.364\end{array}$ & $\begin{array}{c}11 / 1395 \\
0.364\end{array}$ & $\begin{array}{c}11 / 1384 \\
0.360\end{array}$ & $\begin{array}{c}11 / 1395 \\
0.363\end{array}$ & $11 / 1395$ \\
\hline
\end{tabular}

Notes: Dependent variable is change in deposit dollarization. p-values in parentheses based on robust standard errors adjusted for heteroskedasticity and serial correlation for the OLS, FE, and RE estimators, for serial correlation for the FE and RE estimators with AR(1) errors, and for panel heteroskedasticity and panel specific autocorrelation for the FGLS estimator with AR(1) errors. Constant term, and country dummies for the FGLS estimator, not reported. 
Table 3: Deposit Dollarization: Extended Model with High-Dollarization Dummies

\begin{tabular}{|c|c|c|c|c|c|c|}
\hline Variable & $\begin{array}{c}\text { OLS } \\
\text { (1) }\end{array}$ & $\begin{array}{l}\text { FE } \\
\text { (2) }\end{array}$ & $\begin{array}{l}\text { RE } \\
\text { (3) }\end{array}$ & $\begin{array}{c}\text { FE-AR(1) } \\
\text { (4) }\end{array}$ & $\begin{array}{c}\text { RE-AR(1) } \\
\text { (5) }\end{array}$ & $\begin{array}{c}\text { FGLS-PSAR(1) } \\
(6)\end{array}$ \\
\hline High-dollarization dummy & $\begin{array}{c}0.005 \\
(0.002)\end{array}$ & $\begin{array}{c}0.011 \\
(0.000)\end{array}$ & $\begin{array}{c}0.005 \\
(0.000)\end{array}$ & $\begin{array}{c}0.014 \\
(0.000)\end{array}$ & $\begin{array}{c}0.006 \\
(0.000)\end{array}$ & $\begin{array}{c}0.010 \\
(0.000)\end{array}$ \\
\hline Exchange rate factor & $\begin{array}{c}0.698 \\
(0.000)\end{array}$ & $\begin{array}{c}0.690 \\
(0.000)\end{array}$ & $\begin{array}{c}0.698 \\
(0.000)\end{array}$ & $\begin{array}{c}0.731 \\
(0.000)\end{array}$ & $\begin{array}{c}0.708 \\
(0.000)\end{array}$ & $\begin{array}{c}0.674 \\
(0.000)\end{array}$ \\
\hline Exchange rate factor $*$ High-doll & $\begin{array}{c}0.299 \\
(0.036)\end{array}$ & $\begin{array}{c}0.296 \\
(0.000)\end{array}$ & $\begin{array}{c}0.299 \\
(0.036)\end{array}$ & $\begin{array}{c}0.329 \\
(0.000)\end{array}$ & $\begin{array}{c}0.359 \\
(0.000)\end{array}$ & $\begin{array}{c}0.237 \\
(0.001)\end{array}$ \\
\hline Money base factor & $\begin{array}{l}-0.030 \\
(0.801)\end{array}$ & $\begin{array}{l}-0.021 \\
(0.549)\end{array}$ & $\begin{array}{l}-0.030 \\
(0.409)\end{array}$ & $\begin{array}{c}0.006 \\
(0.852)\end{array}$ & $\begin{array}{l}-0.005 \\
(0.876)\end{array}$ & $\begin{array}{l}-0.055 \\
(0.018)\end{array}$ \\
\hline Money base factor $*$ High-doll & $\begin{array}{l}-0.385 \\
(0.061)\end{array}$ & $\begin{array}{l}-0.385 \\
(0.000)\end{array}$ & $\begin{array}{l}-0.385 \\
(0.061)\end{array}$ & $\begin{array}{l}-0.449 \\
(0.000)\end{array}$ & $\begin{array}{l}-0.439 \\
(0.000)\end{array}$ & $\begin{array}{l}-0.327 \\
(0.000)\end{array}$ \\
\hline Error correction & $\begin{array}{c}0.132 \\
(0.000)\end{array}$ & $\begin{array}{c}0.146 \\
(0.000)\end{array}$ & $\begin{array}{c}0.132 \\
(0.000)\end{array}$ & $\begin{array}{c}0.133 \\
(0.000)\end{array}$ & $\begin{array}{c}0.120 \\
(0.000)\end{array}$ & $\begin{array}{c}0.142 \\
(0.000)\end{array}$ \\
\hline Interest rate differential & $\begin{array}{c}-0.009 \\
(0.001)\end{array}$ & $\begin{array}{c}-0.010 \\
(0.000)\end{array}$ & $\begin{array}{c}-0.009 \\
(0.000)\end{array}$ & $\begin{array}{l}-0.010 \\
(0.000)\end{array}$ & $\begin{array}{c}-0.009 \\
(0.000)\end{array}$ & $\begin{array}{c}-0.008 \\
(0.000)\end{array}$ \\
\hline Minimum variance portfolio & $\begin{array}{c}0.000 \\
(0.662)\end{array}$ & $\begin{array}{l}-0.000 \\
(0.693)\end{array}$ & $\begin{array}{c}0.000 \\
(0.633)\end{array}$ & $\begin{array}{l}-0.000 \\
(0.829)\end{array}$ & $\begin{array}{c}0.000 \\
(0.686)\end{array}$ & $\begin{array}{c}-0.000 \\
(0.965)\end{array}$ \\
\hline Change in inflation rate & $\begin{array}{l}-0.002 \\
(0.850)\end{array}$ & $\begin{array}{l}-0.003 \\
(0.773)\end{array}$ & $\begin{array}{l}-0.002 \\
(0.824)\end{array}$ & $\begin{array}{l}-0.007 \\
(0.493)\end{array}$ & $\begin{array}{l}-0.005 \\
(0.609)\end{array}$ & $\begin{array}{c}0.007 \\
(0.464)\end{array}$ \\
\hline Asymmetry & $\begin{array}{c}-0.001 \\
(0.099)\end{array}$ & $\begin{array}{c}-0.001 \\
(0.039)\end{array}$ & $\begin{array}{c}-0.001 \\
(0.024)\end{array}$ & $\begin{array}{c}-0.001 \\
(0.056)\end{array}$ & $\begin{array}{c}-0.001 \\
(0.050)\end{array}$ & $\begin{array}{c}-0.001 \\
(0.001)\end{array}$ \\
\hline Intervention & $\begin{array}{c}0.001 \\
(0.593) \\
\end{array}$ & $\begin{array}{c}0.001 \\
(0.526) \\
\end{array}$ & $\begin{array}{c}0.001 \\
(0.581) \\
\end{array}$ & $\begin{array}{c}0.001 \\
(0.724) \\
\end{array}$ & $\begin{array}{c}0.001 \\
(0.689) \\
\end{array}$ & $\begin{array}{c}-0.000 \\
(0.992) \\
\end{array}$ \\
\hline Countries / Obs & $11 / 1395$ & $11 / 1395$ & $11 / 1395$ & $11 / 1384$ & $11 / 1395$ & $11 / 1395$ \\
\hline R-square & 0.389 & 0.369 & 0.389 & 0.351 & 0.388 & \\
\hline Sum of exchange rate variables equal one & 0.982 & 0.861 & 0.968 & 0.456 & 0.413 & 0.192 \\
\hline
\end{tabular}

Notes: Dependent variable is change in deposit dollarization. p-values in parentheses based on robust standard errors adjusted for heteroskedasticity and serial correlation for the OLS, FE, and RE estimators, for serial correlation for the FE and RE estimators with AR(1) errors, and for panel heteroskedasticity and panel specific autocorrelation for the FGLS estimator with AR(1) errors. Constant term, and country dummies for the FGLS estimator, not reported. The tests of 'exchange rate factor + exchange rate factor $*$ high-doll $=1$ ' are $F$-statistic for all estimators except for the RE-AR( 1$)$ estimator which is a Chisquare statistic ( $\mathrm{p}$-values are reported). 
Table 4: Loan Dollarization: Benchmark and Extended Model with High-Dollarization Dummies

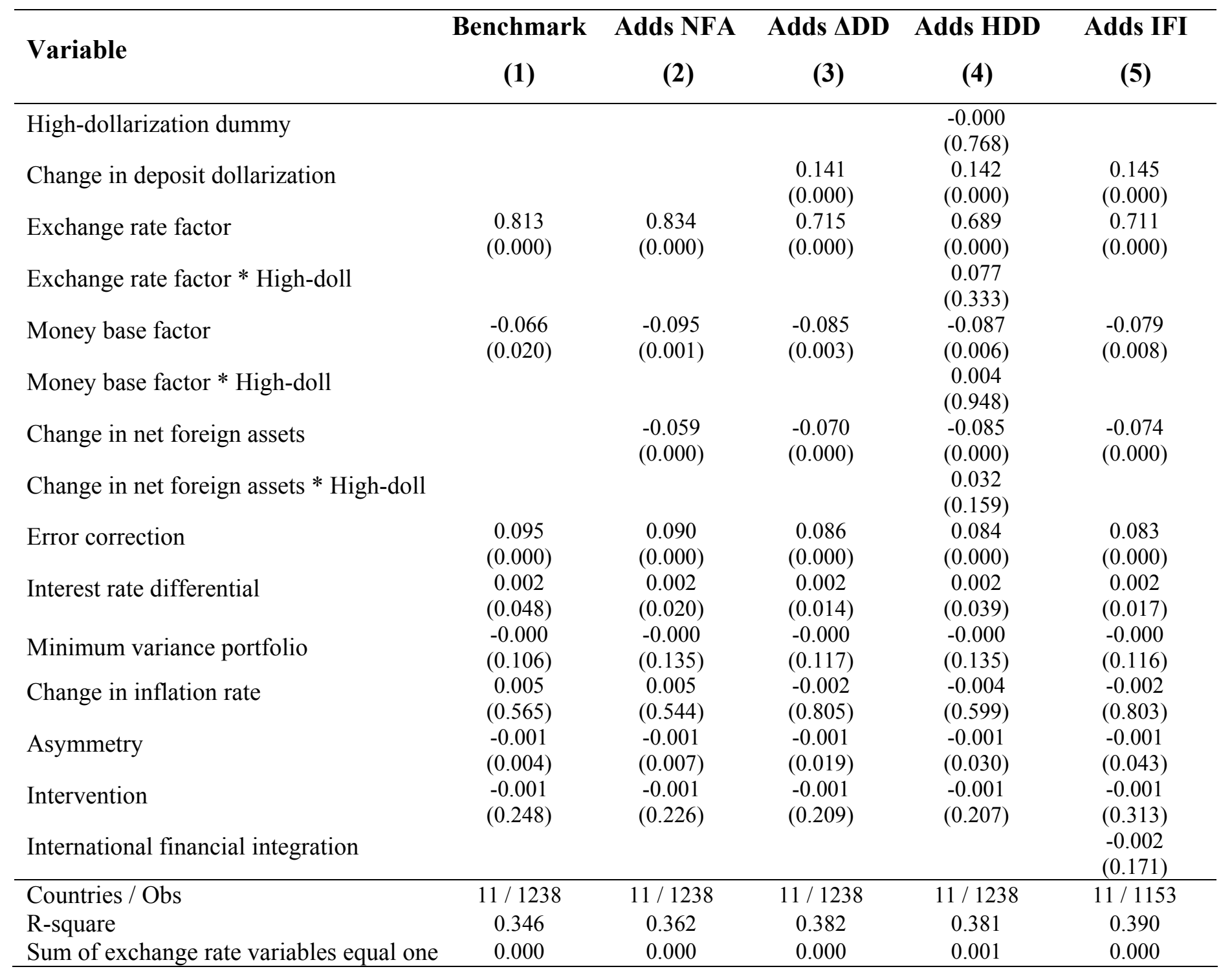

Notes: Dependent variable is change in loan dollarization. All columns report results based on the FE estimator (findings are similar with RE estimator, FE and RE estimators with AR(1) errors, and FGLS estimator with AR(1) errors). p-values in parentheses based on robust standard errors adjusted for heteroskedasticity and serial correlation. Constant term not reported. The tests of 'exchange rate factor + exchange rate factor * high-doll $=1$ ' are $F$-statistic for all estimators ( $p$-values are reported). 
Table 5: Loan Dollarization: Alternative Regression Techniques

\begin{tabular}{|c|c|c|c|c|c|c|}
\hline Variable & $\begin{array}{l}\text { RE } \\
\text { (1) }\end{array}$ & $\begin{array}{c}\text { FE-AR(1) } \\
\text { (2) }\end{array}$ & $\begin{array}{c}\text { RE-AR(1) } \\
\text { (3) }\end{array}$ & $\begin{array}{c}\text { FGLS-PSAR(1) } \\
\text { (4) }\end{array}$ & $\begin{array}{c}\text { 2SLS-FE } \\
\text { (5) }\end{array}$ & $\begin{array}{c}\text { 2SLS-RE } \\
\text { (6) }\end{array}$ \\
\hline Change in deposit dollarization & $\begin{array}{c}0.157 \\
(0.000)\end{array}$ & $\begin{array}{c}0.148 \\
(0.000)\end{array}$ & $\begin{array}{c}0.150 \\
(0.000)\end{array}$ & $\begin{array}{c}0.067 \\
(0.005)\end{array}$ & $\begin{array}{c}0.083 \\
(0.026)\end{array}$ & $\begin{array}{c}0.095 \\
(0.010)\end{array}$ \\
\hline Exchange rate factor & $\begin{array}{c}0.700 \\
(0.000)\end{array}$ & $\begin{array}{c}0.716 \\
(0.000)\end{array}$ & $\begin{array}{c}0.706 \\
(0.000)\end{array}$ & $\begin{array}{c}0.823 \\
(0.000)\end{array}$ & $\begin{array}{c}1.015 \\
(0.000)\end{array}$ & $\begin{array}{c}1.012 \\
(0.000)\end{array}$ \\
\hline Money base factor & $\begin{array}{l}-0.091 \\
(0.002)\end{array}$ & $\begin{array}{l}-0.086 \\
(0.003)\end{array}$ & $\begin{array}{l}-0.088 \\
(0.003)\end{array}$ & $\begin{array}{l}-0.013 \\
(0.539)\end{array}$ & $\begin{array}{l}-0.129 \\
(0.001)\end{array}$ & $\begin{array}{l}-0.134 \\
(0.000)\end{array}$ \\
\hline Change in net foreign assets & $\begin{array}{l}-0.077 \\
(0.000)\end{array}$ & $\begin{array}{l}-0.075 \\
(0.000)\end{array}$ & $\begin{array}{l}-0.076 \\
(0.000)\end{array}$ & $\begin{array}{l}-0.055 \\
(0.000)\end{array}$ & $\begin{array}{l}-0.062 \\
(0.000)\end{array}$ & $\begin{array}{l}-0.066 \\
(0.000)\end{array}$ \\
\hline Error correction & $\begin{array}{c}0.075 \\
(0.000)\end{array}$ & $\begin{array}{c}0.080 \\
(0.000)\end{array}$ & $\begin{array}{c}0.077 \\
(0.000)\end{array}$ & $\begin{array}{c}0.090 \\
(0.000)\end{array}$ & $\begin{array}{c}0.075 \\
(0.000)\end{array}$ & $\begin{array}{c}0.071 \\
(0.000)\end{array}$ \\
\hline Interest rate differential & $\begin{array}{c}0.001 \\
(0.272)\end{array}$ & $\begin{array}{c}0.002 \\
(0.043)\end{array}$ & $\begin{array}{c}0.002 \\
(0.075)\end{array}$ & $\begin{array}{c}0.002 \\
(0.211)\end{array}$ & $\begin{array}{c}0.004 \\
(0.012)\end{array}$ & $\begin{array}{c}0.002 \\
(0.098)\end{array}$ \\
\hline Minimum variance portfolio & $\begin{array}{l}-0.000 \\
(0.017)\end{array}$ & $\begin{array}{l}-0.000 \\
(0.114)\end{array}$ & $\begin{array}{l}-0.000 \\
(0.048)\end{array}$ & $\begin{array}{l}-0.000 \\
(0.300)\end{array}$ & $\begin{array}{l}-0.000 \\
(0.837)\end{array}$ & $\begin{array}{l}-0.000 \\
(0.382)\end{array}$ \\
\hline Change in inflation rate & $\begin{array}{l}-0.002 \\
(0.805)\end{array}$ & $\begin{array}{l}-0.001 \\
(0.861)\end{array}$ & $\begin{array}{l}-0.001 \\
(0.883)\end{array}$ & $\begin{array}{c}0.006 \\
(0.584)\end{array}$ & $\begin{array}{c}0.051 \\
(0.074)\end{array}$ & $\begin{array}{c}0.048 \\
(0.097)\end{array}$ \\
\hline Asymmetry & $\begin{array}{l}-0.001 \\
(0.018)\end{array}$ & $\begin{array}{l}-0.001 \\
(0.059)\end{array}$ & $\begin{array}{l}-0.001 \\
(0.059)\end{array}$ & $\begin{array}{l}-0.001 \\
(0.000)\end{array}$ & $\begin{array}{l}-0.009 \\
(0.018)\end{array}$ & $\begin{array}{l}-0.009 \\
(0.007)\end{array}$ \\
\hline Intervention & $\begin{array}{l}-0.003 \\
(0.003)\end{array}$ & $\begin{array}{l}-0.001 \\
(0.298)\end{array}$ & $\begin{array}{l}-0.002 \\
(0.058)\end{array}$ & $\begin{array}{l}-0.001 \\
(0.456)\end{array}$ & $\begin{array}{l}-0.000 \\
(0.954)\end{array}$ & $\begin{array}{l}-0.001 \\
(0.301)\end{array}$ \\
\hline International financial integration & $\begin{array}{c}-0.002 \\
(0.004)\end{array}$ & $\begin{array}{l}-0.002 \\
(0.183)\end{array}$ & $\begin{array}{l}-0.002 \\
(0.045)\end{array}$ & $\begin{array}{l}-0.003 \\
(0.011)\end{array}$ & $\begin{array}{l}-0.004 \\
(0.028)\end{array}$ & $\begin{array}{l}-0.004 \\
(0.001)\end{array}$ \\
\hline Countries / Obs & $11 / 1153$ & $11 / 1142$ & $11 / 1153$ & $11 / 1153$ & $11 / 1150$ & $11 / 1150$ \\
\hline R-square & 0.393 & 0.391 & 0.393 & & 0.266 & 0.270 \\
\hline
\end{tabular}


Table 6: Deposit Dollarization: Extended Model controlling for Endogeneity

\begin{tabular}{|c|c|c|c|c|}
\hline Variable & $\begin{array}{c}\text { 2SLS-FE } \\
\text { (1) }\end{array}$ & $\begin{array}{c}\text { 2SLS-RE } \\
\text { (2) }\end{array}$ & $\begin{array}{c}\text { 2SLS-FE } \\
\text { (3) }\end{array}$ & $\begin{array}{c}\text { 2SLS-RE } \\
\text { (4) }\end{array}$ \\
\hline High-dollarization dummy & $\begin{array}{c}0.012 \\
(0.000)\end{array}$ & $\begin{array}{c}0.005 \\
(0.000)\end{array}$ & $\begin{array}{c}0.020 \\
(0.000)\end{array}$ & $\begin{array}{c}0.015 \\
(0.001)\end{array}$ \\
\hline Exchange rate factor & $\begin{array}{c}0.715 \\
(0.000)\end{array}$ & $\begin{array}{c}0.725 \\
(0.000)\end{array}$ & $\begin{array}{c}0.788 \\
(0.007)\end{array}$ & $\begin{array}{c}0.695 \\
(0.023)\end{array}$ \\
\hline Exchange rate factor $*$ High-doll & $\begin{array}{c}0.220 \\
(0.028)\end{array}$ & $\begin{array}{c}0.232 \\
(0.020)\end{array}$ & $\begin{array}{c}1.60 \\
(0.025)\end{array}$ & $\begin{array}{c}1.95 \\
(0.024)\end{array}$ \\
\hline Money base factor & $\begin{array}{l}-0.014 \\
(0.703)\end{array}$ & $\begin{array}{l}-0.024 \\
(0.516)\end{array}$ & $\begin{array}{c}0.459 \\
(0.080)\end{array}$ & $\begin{array}{c}0.570 \\
(0.060)\end{array}$ \\
\hline Money base factor * High-doll & $\begin{array}{l}-0.382 \\
(0.000)\end{array}$ & $\begin{array}{l}-0.383 \\
(0.000)\end{array}$ & $\begin{array}{c}-2.93 \\
(0.008)\end{array}$ & $\begin{array}{c}-3.33 \\
(0.011)\end{array}$ \\
\hline Error correction & $\begin{array}{c}0.144 \\
(0.000)\end{array}$ & $\begin{array}{c}0.129 \\
(0.000)\end{array}$ & $\begin{array}{c}0.102 \\
(0.006)\end{array}$ & $\begin{array}{c}0.095 \\
(0.013)\end{array}$ \\
\hline Interest rate differential & $\begin{array}{c}-0.010 \\
(0.000)\end{array}$ & $\begin{array}{l}-0.009 \\
(0.000)\end{array}$ & $\begin{array}{l}-0.012 \\
(0.006)\end{array}$ & $\begin{array}{l}-0.013 \\
(0.006)\end{array}$ \\
\hline Minimum variance portfolio & $\begin{array}{l}-0.000 \\
(0.744)\end{array}$ & $\begin{array}{c}0.000 \\
(0.591)\end{array}$ & $\begin{array}{c}0.000 \\
(0.721)\end{array}$ & $\begin{array}{c}0.000 \\
(0.557)\end{array}$ \\
\hline Change in inflation rate & $\begin{array}{c}0.019 \\
(0.480)\end{array}$ & $\begin{array}{c}0.016 \\
(0.540)\end{array}$ & $\begin{array}{c}0.005 \\
(0.897)\end{array}$ & $\begin{array}{c}0.006 \\
(0.886)\end{array}$ \\
\hline Asymmetry & $\begin{array}{l}-0.001 \\
(0.707)\end{array}$ & $\begin{array}{l}-0.001 \\
(0.634)\end{array}$ & $\begin{array}{l}-0.004 \\
(0.398)\end{array}$ & $\begin{array}{c}-0.004 \\
(0.347)\end{array}$ \\
\hline Intervention & $\begin{array}{c}0.001 \\
(0.629) \\
\end{array}$ & $\begin{array}{c}0.001 \\
(0.660) \\
\end{array}$ & $\begin{array}{c}0.004 \\
(0.181) \\
\end{array}$ & $\begin{array}{c}0.001 \\
(0.531)\end{array}$ \\
\hline Countries / Obs & $11 / 1385$ & $11 / 1385$ & $11 / 1385$ & $11 / 1385$ \\
\hline R-square & 0.362 & 0.384 & 0.225 & 0.195 \\
\hline
\end{tabular}


Table 7: Deposit Dollarization: Extended Model - Sensitivity Analysis

\begin{tabular}{|c|c|c|c|c|c|c|c|}
\hline Variable & $\begin{array}{c}\text { Dummy }>75 \% \\
\text { (1) }\end{array}$ & $\begin{array}{l}3 \text { region Dum } \\
\text { (2) }\end{array}$ & $\begin{array}{c}\text { MVP2 } \\
\text { (3) }\end{array}$ & $\begin{array}{c}\text { Errorcor6 } \\
\text { (4) }\end{array}$ & $\begin{array}{c}\text { Post-1996 } \\
\text { (5) }\end{array}$ & $\begin{array}{c}\text { Corruption } \\
\text { (6) }\end{array}$ & $\begin{array}{c}\text { Extra controls } \\
\text { (7) }\end{array}$ \\
\hline High-dollarization dummy & $\begin{array}{c}0.010 \\
(0.000)\end{array}$ & $\begin{array}{c}0.009 \\
(0.000)\end{array}$ & $\begin{array}{c}0.011 \\
(0.000)\end{array}$ & $\begin{array}{c}0.008 \\
(0.000)\end{array}$ & $\begin{array}{c}0.009 \\
(0.000)\end{array}$ & $\begin{array}{c}0.012 \\
(0.000)\end{array}$ & $\begin{array}{c}0.012 \\
(0.000)\end{array}$ \\
\hline Exchange rate factor & $\begin{array}{c}0.694 \\
(0.000)\end{array}$ & $\begin{array}{c}0.486 \\
(0.000)\end{array}$ & $\begin{array}{c}0.693 \\
(0.000)\end{array}$ & $\begin{array}{c}0.766 \\
(0.000)\end{array}$ & $\begin{array}{c}0.764 \\
(0.000)\end{array}$ & $\begin{array}{c}0.778 \\
(0.000)\end{array}$ & $\begin{array}{c}0.696 \\
(0.000)\end{array}$ \\
\hline Exchange rate factor $*$ High-doll & $\begin{array}{c}0.358 \\
(0.000)\end{array}$ & $\begin{array}{c}0.234 \\
(0.000)\end{array}$ & $\begin{array}{c}0.290 \\
(0.000)\end{array}$ & $\begin{array}{c}0.249 \\
(0.002)\end{array}$ & $\begin{array}{c}0.268 \\
(0.001)\end{array}$ & $\begin{array}{c}0.159 \\
(0.030)\end{array}$ & $\begin{array}{c}0.248 \\
(0.001)\end{array}$ \\
\hline Money base factor & $\begin{array}{l}-0.041 \\
(0.243)\end{array}$ & $\begin{array}{c}0.052 \\
(0.350)\end{array}$ & $\begin{array}{l}-0.022 \\
(0.548)\end{array}$ & $\begin{array}{l}-0.074 \\
(0.050)\end{array}$ & $\begin{array}{l}-0.014 \\
(0.702)\end{array}$ & $\begin{array}{c}0.007 \\
(0.821)\end{array}$ & $\begin{array}{c}0.011 \\
(0.772)\end{array}$ \\
\hline Money base factor * High-doll & $\begin{array}{l}-0.403 \\
(0.000)\end{array}$ & $\begin{array}{l}-0.167 \\
(0.000)\end{array}$ & $\begin{array}{c}-0.388 \\
(0.000)\end{array}$ & $\begin{array}{l}-0.370 \\
(0.000)\end{array}$ & $\begin{array}{l}-0.459 \\
(0.000)\end{array}$ & $\begin{array}{l}-0.395 \\
(0.000)\end{array}$ & $\begin{array}{l}-0.398 \\
(0.000)\end{array}$ \\
\hline Error correction & $\begin{array}{c}0.141 \\
(0.000)\end{array}$ & $\begin{array}{c}0.149 \\
(0.000)\end{array}$ & $\begin{array}{c}0.145 \\
(0.000)\end{array}$ & $\begin{array}{c}0.061 \\
(0.000)\end{array}$ & $\begin{array}{c}0.121 \\
(0.000)\end{array}$ & $\begin{array}{c}0.106 \\
(0.000)\end{array}$ & $\begin{array}{c}0.138 \\
(0.000)\end{array}$ \\
\hline Interest rate differential & $\begin{array}{l}-0.010 \\
(0.000)\end{array}$ & $\begin{array}{c}-0.008 \\
(0.000)\end{array}$ & $\begin{array}{l}-0.010 \\
(0.000)\end{array}$ & $\begin{array}{l}-0.010 \\
(0.000)\end{array}$ & $\begin{array}{l}-0.007 \\
(0.036)\end{array}$ & $\begin{array}{l}-0.004 \\
(0.137)\end{array}$ & $\begin{array}{l}-0.008 \\
(0.000)\end{array}$ \\
\hline Minimum variance portfolio & $\begin{array}{l}-0.000 \\
(0.818)\end{array}$ & $\begin{array}{l}-0.000 \\
(0.879)\end{array}$ & $\begin{array}{c}0.002 \\
(0.460)\end{array}$ & $\begin{array}{c}0.000 \\
(0.946)\end{array}$ & $\begin{array}{l}-0.000 \\
(0.252)\end{array}$ & $\begin{array}{l}-0.000 \\
(0.739)\end{array}$ & $\begin{array}{l}-0.000 \\
(0.629)\end{array}$ \\
\hline Change in inflation rate & $\begin{array}{l}-0.007 \\
(0.510)\end{array}$ & $\begin{array}{l}-0.003 \\
(0.756)\end{array}$ & $\begin{array}{c}-0.002 \\
(0.796)\end{array}$ & $\begin{array}{c}0.009 \\
(0.403)\end{array}$ & $\begin{array}{l}-0.007 \\
(0.472)\end{array}$ & $\begin{array}{c}0.001 \\
(0.943)\end{array}$ & $\begin{array}{c}0.002 \\
(0.851)\end{array}$ \\
\hline Asymmetry & $\begin{array}{l}-0.001 \\
(0.052)\end{array}$ & $\begin{array}{l}-0.001 \\
(0.105)\end{array}$ & $\begin{array}{l}-0.001 \\
(0.039)\end{array}$ & $\begin{array}{l}-0.001 \\
(0.051)\end{array}$ & $\begin{array}{l}-0.001 \\
(0.015)\end{array}$ & $\begin{array}{l}-0.001 \\
(0.136)\end{array}$ & $\begin{array}{l}-0.001 \\
(0.030)\end{array}$ \\
\hline Intervention & $\begin{array}{c}0.001 \\
(0.405)\end{array}$ & $\begin{array}{c}0.001 \\
(0.934)\end{array}$ & $\begin{array}{c}0.001 \\
(0.539)\end{array}$ & $\begin{array}{c}0.001 \\
(0.490)\end{array}$ & $\begin{array}{l}-0.000 \\
(0.931)\end{array}$ & $\begin{array}{l}-0.002 \\
(0.177)\end{array}$ & $\begin{array}{l}-0.000 \\
(0.882)\end{array}$ \\
\hline Corruption & & & & & & $\begin{array}{l}-0.001 \\
(0.158)\end{array}$ & \\
\hline Max inflation rate & & & & & & & $\begin{array}{l}-0.007 \\
(0.179)\end{array}$ \\
\hline Max depreciation rate & & & & & & & $\begin{array}{c}0.007 \\
(0.179)\end{array}$ \\
\hline European Union membership & & & & & & & $\begin{array}{c}0.001 \\
(0.659)\end{array}$ \\
\hline International financial integration & & & & & & & $\begin{array}{l}-0.001 \\
(0.448)\end{array}$ \\
\hline Russian crisis & & & & & & & $\begin{array}{l}-0.001 \\
(0.724)\end{array}$ \\
\hline Countries / Obs & $11 / 1395$ & $11 / 1395$ & $11 / 1395$ & $11 / 1379$ & $11 / 1235$ & $9 / 823$ & $11 / 1285$ \\
\hline R-square & 0.376 & 0.327 & 0.368 & 0.330 & 0.370 & 0.488 & 0.380 \\
\hline
\end{tabular}


Table 8: Loan Dollarization: Sensitivity Analysis

\begin{tabular}{|c|c|c|c|c|c|c|c|}
\hline Variable & $\begin{array}{c}\text { Dummy }>75 \% \\
\text { (1) }\end{array}$ & $\begin{array}{c}3 \text { region Dum } \\
\text { (2) }\end{array}$ & $\begin{array}{c}\text { MVP2 } \\
\text { (3) }\end{array}$ & $\begin{array}{c}\text { Errorcor6 } \\
\text { (4) }\end{array}$ & $\begin{array}{c}\text { Post-1996 } \\
\text { (5) }\end{array}$ & $\begin{array}{c}\text { Corruption } \\
\text { (6) }\end{array}$ & $\begin{array}{c}\text { Extra controls } \\
\text { (7) }\end{array}$ \\
\hline High-dollarization dummy & $\begin{array}{c}-0.002 \\
(0.225)\end{array}$ & $\begin{array}{c}0.000 \\
(0.859)\end{array}$ & & & & & \\
\hline Change in deposit dollarization & $\begin{array}{c}0.152 \\
(0.000)\end{array}$ & $\begin{array}{c}0.149 \\
(0.000)\end{array}$ & $\begin{array}{c}0.145 \\
(0.000)\end{array}$ & $\begin{array}{c}0.148 \\
(0.000)\end{array}$ & $\begin{array}{c}0.219 \\
(0.000)\end{array}$ & $\begin{array}{c}0.187 \\
(0.000)\end{array}$ & $\begin{array}{c}0.138 \\
(0.000)\end{array}$ \\
\hline Exchange rate factor & $\begin{array}{c}0.720 \\
(0.000)\end{array}$ & $\begin{array}{c}0.725 \\
(0.000)\end{array}$ & $\begin{array}{c}0.719 \\
(0.000)\end{array}$ & $\begin{array}{c}0.674 \\
(0.000)\end{array}$ & $\begin{array}{c}0.654 \\
(0.000)\end{array}$ & $\begin{array}{c}0.775 \\
(0.000)\end{array}$ & $\begin{array}{c}0.678 \\
(0.000)\end{array}$ \\
\hline Exchange rate factor $*$ High-doll & $\begin{array}{c}0.010 \\
(0.904)\end{array}$ & $\begin{array}{l}-0.003 \\
(0.958)\end{array}$ & & & & & \\
\hline Money base factor & $\begin{array}{c}0.014 \\
(0.773)\end{array}$ & $\begin{array}{c}0.128 \\
(0.228)\end{array}$ & $\begin{array}{l}-0.078 \\
(0.009)\end{array}$ & $\begin{array}{l}-0.086 \\
(0.003)\end{array}$ & $\begin{array}{l}-0.060 \\
(0.052)\end{array}$ & $\begin{array}{l}-0.078 \\
(0.016)\end{array}$ & $\begin{array}{l}-0.077 \\
(0.010)\end{array}$ \\
\hline Money base factor * High-doll & $\begin{array}{l}-0.151 \\
(0.014)\end{array}$ & $\begin{array}{l}-0.084 \\
(0.042)\end{array}$ & & & & & \\
\hline Change in net foreign assets & $\begin{array}{l}-0.085 \\
(0.006)\end{array}$ & $\begin{array}{l}-0.115 \\
(0.099)\end{array}$ & $\begin{array}{c}-0.074 \\
(0.000)\end{array}$ & $\begin{array}{l}-0.075 \\
(0.000)\end{array}$ & $\begin{array}{l}-0.070 \\
(0.000)\end{array}$ & $\begin{array}{l}-0.067 \\
(0.000)\end{array}$ & $\begin{array}{l}-0.071 \\
(0.000)\end{array}$ \\
\hline Change in net foreign assets $*$ High-doll & $\begin{array}{c}0.010 \\
(0.746)\end{array}$ & $\begin{array}{c}0.014 \\
(0.570)\end{array}$ & & & & & \\
\hline Error correction & $\begin{array}{c}0.076 \\
(0.000)\end{array}$ & $\begin{array}{c}0.081 \\
(0.000)\end{array}$ & $\begin{array}{c}0.083 \\
(0.000)\end{array}$ & $\begin{array}{c}0.100 \\
(0.000)\end{array}$ & $\begin{array}{c}0.077 \\
(0.000)\end{array}$ & $\begin{array}{c}0.066 \\
(0.000)\end{array}$ & $\begin{array}{c}0.079 \\
(0.000)\end{array}$ \\
\hline Interest rate differential & $\begin{array}{c}0.002 \\
(0.005)\end{array}$ & $\begin{array}{c}0.002 \\
(0.014)\end{array}$ & $\begin{array}{c}0.002 \\
(0.013)\end{array}$ & $\begin{array}{l}-0.001 \\
(0.390)\end{array}$ & $\begin{array}{c}0.002 \\
(0.021)\end{array}$ & $\begin{array}{c}0.003 \\
(0.002)\end{array}$ & $\begin{array}{c}0.002 \\
(0.015)\end{array}$ \\
\hline Minimum variance portfolio & $\begin{array}{l}-0.000 \\
(0.096)\end{array}$ & $\begin{array}{l}-0.000 \\
(0.109)\end{array}$ & $\begin{array}{l}-0.003 \\
(0.403)\end{array}$ & $\begin{array}{l}-0.000 \\
(0.042)\end{array}$ & $\begin{array}{l}-0.000 \\
(0.185)\end{array}$ & $\begin{array}{l}-0.000 \\
(0.112)\end{array}$ & $\begin{array}{l}-0.000 \\
(0.233)\end{array}$ \\
\hline Change in inflation rate & $\begin{array}{l}-0.003 \\
(0.709)\end{array}$ & $\begin{array}{l}-0.002 \\
(0.769)\end{array}$ & $\begin{array}{l}-0.001 \\
(0.869)\end{array}$ & $\begin{array}{c}0.004 \\
(0.572)\end{array}$ & $\begin{array}{l}-0.005 \\
(0.529)\end{array}$ & $\begin{array}{l}-0.008 \\
(0.336)\end{array}$ & $\begin{array}{l}-0.005 \\
(0.539)\end{array}$ \\
\hline Asymmetry & $\begin{array}{c}-0.001 \\
(0.062)\end{array}$ & $\begin{array}{l}-0.001 \\
(0.063)\end{array}$ & $\begin{array}{c}-0.001 \\
(0.030)\end{array}$ & $\begin{array}{l}-0.001 \\
(0.023)\end{array}$ & $\begin{array}{c}-0.001 \\
(0.040)\end{array}$ & $\begin{array}{l}-0.001 \\
(0.012)\end{array}$ & $\begin{array}{l}-0.001 \\
(0.077)\end{array}$ \\
\hline Intervention & $\begin{array}{c}-0.001 \\
(0.364)\end{array}$ & $\begin{array}{l}-0.001 \\
(0.338)\end{array}$ & $\begin{array}{l}-0.001 \\
(0.296)\end{array}$ & $\begin{array}{l}-0.001 \\
(0.418)\end{array}$ & $\begin{array}{c}-0.001 \\
(0.514)\end{array}$ & $\begin{array}{l}-0.001 \\
(0.308)\end{array}$ & $\begin{array}{l}-0.001 \\
(0.358)\end{array}$ \\
\hline International financial integration & $\begin{array}{c}-0.001 \\
(0.598)\end{array}$ & $\begin{array}{l}-0.001 \\
(0.277)\end{array}$ & $\begin{array}{c}-0.002 \\
(0.168)\end{array}$ & $\begin{array}{c}0.000 \\
(0.936)\end{array}$ & $\begin{array}{l}-0.004 \\
(0.021)\end{array}$ & $\begin{array}{l}-0.010 \\
(0.000)\end{array}$ & $\begin{array}{l}-0.004 \\
(0.041)\end{array}$ \\
\hline Corruption & & & & & & $\begin{array}{l}-0.003 \\
(0.000)\end{array}$ & \\
\hline Max inflation rate & & & & & & & $\begin{array}{c}0.009 \\
(0.091)\end{array}$ \\
\hline Max depreciation rate & & & & & & & $\begin{array}{c}0.011 \\
(0.020)\end{array}$ \\
\hline European Union membership & & & & & & & $\begin{array}{c}0.000 \\
(0.929)\end{array}$ \\
\hline Russian crisis & & & & & & & $\begin{array}{c}-0.001 \\
(0.748) \\
\end{array}$ \\
\hline Countries / Obs & $11 / 1153$ & $11 / 1153$ & $11 / 1153$ & $11 / 1134$ & $11 / 1067$ & $9 / 745$ & $11 / 1153$ \\
\hline R-square & 0.381 & 0.392 & 0.385 & 0.423 & 0.410 & 0.468 & 0.392 \\
\hline
\end{tabular}

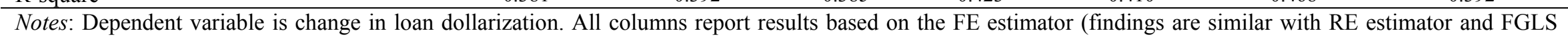

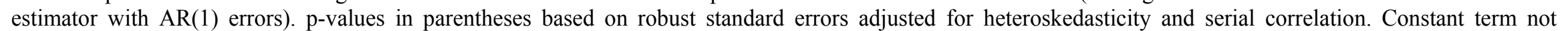
reported. 
Table 9: Deposit Dollarization: Extended Model with Low, Medium, and High Regions

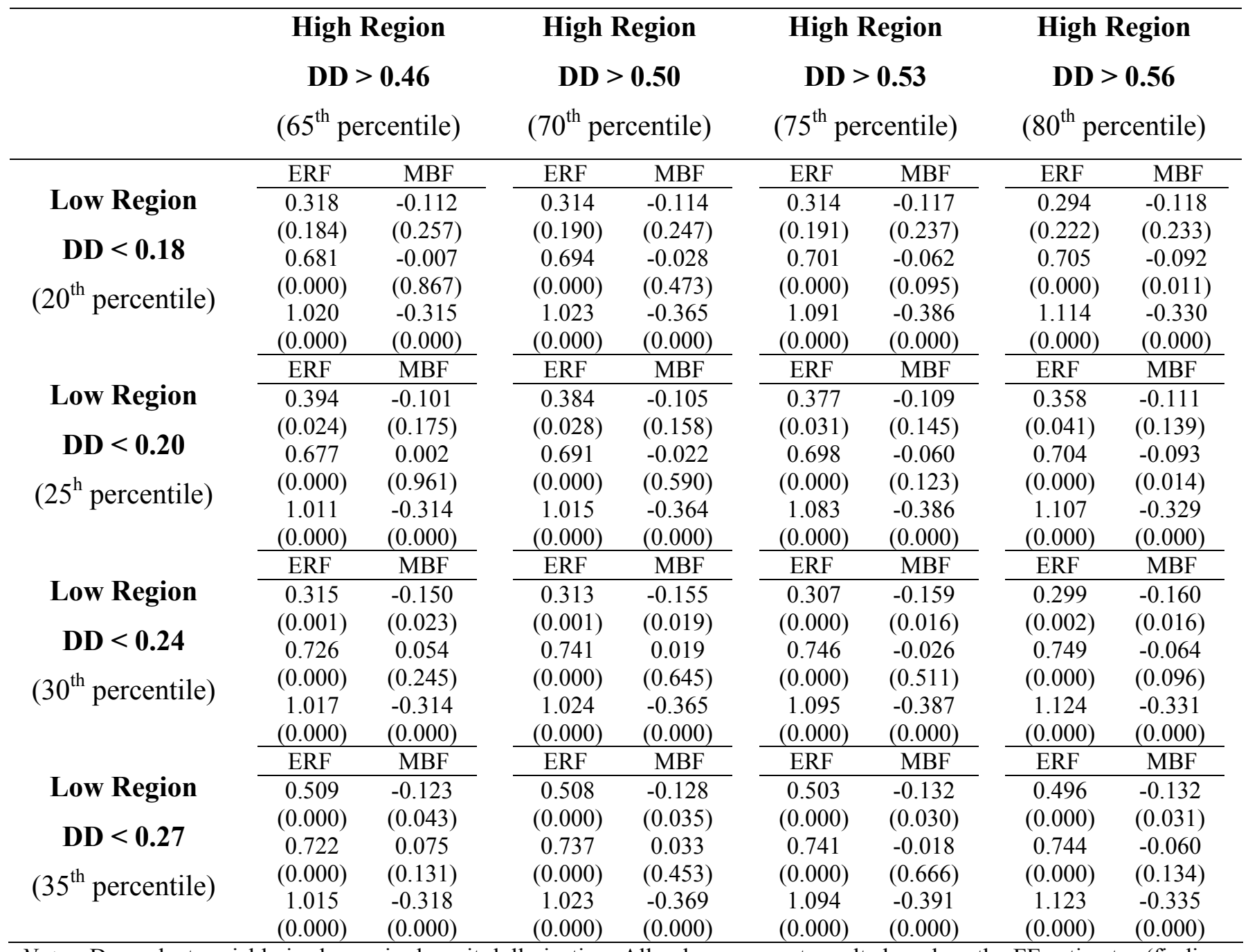

Notes: Dependent variable is change in deposit dollarization. All columns report results based on the FE estimator (findings are similar with RE estimator and FGLS estimator with AR(1) errors). Estimates are for low, medium, and high regions, respectively. p-values in parentheses based on robust standard errors adjusted for heteroskedasticity and serial correlation. Constant term not reported. 


\section{APPENDIX I}

\section{Derivation of the direct effects}

Define the dollarization share as $D$, the foreign currency value of foreign currency holdings as $f$, the local currency value of local currency holdings as $c$, and the exchange rate (local currency price of foreign exchange) as $e$, the dollarization share is

$$
D_{t}=\frac{e_{t} f_{t}}{c_{t}+e_{t} f_{t}} .
$$

In addition, the value ratio of foreign to domestic currency holdings, $v$, is

$$
v_{t} \equiv \frac{e_{t} f_{t}}{c_{t}} \text {. }
$$

Now, consider that depreciation will change the value ratio, $v$, even if $f$ and $c$ remain unchanged. This effect is captured by

$$
\Delta v=v \Delta \ln e .
$$

But at the same time, the value ratio is also defined as

$$
v_{t}=\frac{D_{t}}{1-D_{t}},
$$

so that total differentiation yields the approximation

$$
\Delta v=\frac{\Delta D}{(1-D)^{2}}
$$

Combining equations (I3) and (I5) yields the short-run effect of exchange rate changes on the dollarization share (or the exchange rate factor)

$$
\Delta D=(1-D) D \Delta \ln e \text {. }
$$

Following Honohan (2007), we also derive an additional mechanical effect related with changes in the local-currency monetary base which, under policy control, can eventually affect $c$. In this way, an accumulation of local currency deposits when $f$ and $e$ remain unaltered would shift the dollarization ratio by $\Delta D=(1-D) D \Delta \ln c$. This represents the money base factor. 


\section{APPENDIX II}

\section{Computation of MVP}

MVP is computed through the following two specifications suggested in the literature:

$$
M V P 1_{t}=\frac{\sigma_{v_{t}}^{2}}{\operatorname{COV}_{\mathrm{vu}_{\mathrm{t}}}} \text { and } M V P 2_{t}=\frac{\rho_{\mathrm{vu}_{\mathrm{t}}} \sigma_{v_{t}}}{\sigma_{\mathrm{u}_{\mathrm{t}}}} .
$$

MVP1 is proposed by Levy-Yeyati (2006) while MVP2 by Rennhack and Nozaki (2006). ${ }^{1}$ In the formulas, $\sigma_{v t}^{2}$ and $\sigma_{u t}^{2}$ stand for the conditional variances of inflation and of depreciation of the nominal exchange rate respectively, $C O V_{v u t}$ represents the conditional covariance between inflation and the depreciation of the nominal exchange rate, and $\rho_{\mathrm{vu}_{\mathrm{t}}}$ describes their conditional correlation coefficient.

To estimate both measures of MVP, we utilize the model developed by Grier and Perry (2000), namely the bivariate GARCH- $M$ system for inflation and the depreciation of the nominal exchange rate. This model allows us to simultaneously estimate equations for the means of inflation and of the depreciation of the exchange rate that include the conditional variance of both (or some of the) series as regressors. ${ }^{2}$ Although several parameterizations of the general multivariate model are possible, we opt to utilize the dynamic conditional correlation (DCC) model of Engle (2002) to estimate the conditional covariance matrix. In this specification, the conditional covariance matrix and the conditional correlation are time-varying. ${ }^{3}$

Let $\pi_{t}$ represent inflation and $\mathrm{ex}_{t}$ the depreciation of the exchange rate in period $t$. Both series follow autoregressive processes and our bivariate $\operatorname{GARCH}(1,1)-M$ model for inflation and the depreciation of the exchange rate is described by: $:^{4,5}$

$$
\pi_{t}=\beta_{0}+\beta_{1} t+\beta_{2} \Delta i_{-} d o m_{t}+\beta_{3} \Delta \ln M 2_{t}+\beta_{4} \Delta \ln I P_{t}+\beta_{5} \sigma_{v t}^{2}+\beta_{6} \sigma_{u t}^{2}+\sum \beta_{i} \pi_{t-i}+\sum \beta_{j} e x_{t-j}+v_{t}
$$

\footnotetext{
${ }^{1}$ Given our focus on changes in nominal exchange rates, we have decided to opt for these two measures instead of the original suggested by Ize and Levy-Yeyati (2003) which entails real exchange rates.

${ }^{2}$ We first estimate a simple VAR model for the three equations. However, this specification not only does not account for the effects of the conditional variances of each variable, but also the squared residuals of each variable show the classic volatility clustering of an ARCH process. Therefore, we use a VAR-GARCH in means specification to account for these effects. To conserve space we do not mention these diagnostic tests, which of course are available upon request.

${ }^{3}$ Grier and Perry (2000) assume constant conditional correlation specification. However, assuming constant correlation across time is a very strong assumption (especially for transition economies).

${ }^{4}$ The order of autoregressive processes is determined using the standard Schwartz Bayesian information criterion.

${ }^{5}$ Empirical literature has found that this specification adequately captures the persistence in second moments (e.g., Fornari and Mele 1997; Grier and Perry 2000).
} 


$$
\begin{aligned}
& \sigma_{v t}^{2}=\mu_{0}+\mu_{1} v_{t-1}+\mu_{2} \sigma_{v t-1}^{2} \\
& e x_{t}=\gamma_{0}+\gamma_{1} t+\gamma_{2} \sigma_{u t}^{2}+\sum \gamma_{i} e x_{t-i}+u_{t} \\
& \sigma_{u t}^{2}=\lambda_{0}+\lambda_{1} u_{t-1}+\lambda_{2} \sigma_{u t-1}^{2}
\end{aligned}
$$

The conditional covariance matrix is given by:

$$
C O V_{v u t}=\rho_{v u t} \sigma_{v t} \sigma_{u t}
$$

where $\rho_{\mathrm{vu}_{\mathrm{t}}}=q_{t}^{*-1} q_{t} q_{t}^{*-1}$ with $q_{\mathrm{t}}=(1-a-b) \bar{q}+a v_{t-1}^{2} u_{t-1}^{2}+q_{\mathrm{t}-1}$ and $q_{i i, t}^{*}=\sqrt{q_{i i, t}}, i=v, u .^{6}$

Equations (II2) and (II4) give the conditional variance of inflation and of the depreciation of the exchange rate respectively. We use these estimated variances as our measures of uncertainty related with inflation and the depreciation of the exchange rate that enter in equations (II1) and (II3).

Following the literature that examines the exchange rate pass-through on inflation (e.g., Billmeier and Bonato 2004; Levy-Yeyati 2006) and the determinants of changes in the exchange rate (e.g., Choudhry 2005), we define equations (II1) and (II3) accordingly. Equation (II1) describes the conditional mean of inflation rate as a function of the change in domestic interest rate, change in the level of M2 and index of industrial production, conditional variances of inflation and of the depreciation of the exchange rate and lagged values of inflation and of the depreciation of the exchange rate. Similarly, equation (II3) describes the conditional mean of the depreciation of the exchange rate as a function of the conditional variance of the depreciation of the exchange rate and lagged values of the depreciation of the exchange rate. Finally, equation (II5) is the dynamic conditional correlation model of the covariance among $v_{t}$ and $u_{t}$.

We assume that all error terms, $v_{t}$ and $u_{t}$ are jointly conditionally normal with zero means and conditional variance given by equations (II2), (II4) and (II5). We estimate the system of equations (II1)-(II5) using the BHHH numerical optimization algorithm to calculate the maximum likelihood estimates of the parameters. ${ }^{7}$ All computations were carried out using GAUSS. Results of the estimated system of equations for each individual country in our sample are available upon request.

\footnotetext{
${ }^{6}$ In order to have $q_{t}$ positive definite, $a$ and $b$ must be greater than zero and their sum smaller than 1. $q$-bar represents the constant unconditional correlation of $v_{t}$ and $u_{t}$.

${ }^{7}$ Bollerslev (1986), using similar assumptions to ours, shows that the BHHH estimate of the asymptotic covariance matrix of the coefficients is consistent.
} 


\section{APPENDIX III}

Table A1: Country Coverage and Dollarization Data Availability

\begin{tabular}{lcccc}
\hline Country & Deposits & Observations & Loans & Observations \\
\hline & & & & \\
Armenia & $1996: 2-2005: 8$ & 115 & $1998: 3-2005: 8$ & 90 \\
Bulgaria & $1996: 2-2005: 8$ & 115 & $1996: 2-2005: 8$ & 115 \\
Czech Rep. & $1993: 3-2004: 3$ & 133 & $1993: 3-2004: 3$ & 133 \\
Estonia & $1994: 2-2005: 8$ & 139 & $1994: 3-2005: 8$ & 138 \\
Georgia & $1996: 1-2006: 2$ & 122 & $1998: 1-2006: 2$ & 98 \\
Kyrgyz Rep. & $1998: 1-2005: 9$ & 93 & $1998: 1-2005: 9$ & 93 \\
Latvia & $1994: 12-2004: 9$ & 118 & $1994: 12-2004: 9$ & 118 \\
Poland & $1993: 3-2005: 9$ & 151 & $1997: 2-2005: 8$ & 103 \\
Romania & $1994: 1-2005: 6$ & 138 & $1994: 2-2004: 12$ & 131 \\
Russia & $1995: 8-2006: 12$ & 137 & $1997: 2-2006: 12$ & 119 \\
Ukraine & $1993: 2-2005: 7$ & 150 & $1995: 1-2005: 7$ & 127 \\
\hline
\end{tabular}




\section{Table A2: Variable Definitions and Sources}

\begin{tabular}{l}
\hline Variable \\
\hline Dependent variables
\end{tabular}

$\Delta$ (Deposit dollarization)

$\Delta$ (Loan dollarization)

Independent variables

Exchange rate factor

Money base factor

Change in net foreign assets

Error correction

Interest rate difference

Minimum variance portfolio

$\Delta$ (Inflation $)$

Asymmetry

Intervention

Inter'l financial integration

Corruption

European Union membership

Inflation maximum

Depreciation maximum

Russian crisis

Start of accession process

Decision to join

Restriction

Variables used to construct

independent variables

$\Delta$ (Exchange rate)

Inflation

\section{Definition [source]}

First difference of (foreign currency denominated deposits to total deposits) of residents held in resident banks*100 [IMF, International Financial Statistics (IFS) and National Central Banks (NCB)]

First difference of (foreign currency denominated credit to total credits) of residents issued by resident banks*100 [IFS and NCB]

Deposit dollarization*(1-deposit dollarization)* $\Delta$ (exchange rate) for deposits

Loan dollarization*(1-loan dollarization)* $\Delta$ (exchange rate) for credits

Deposit dollarization*(1-deposit dollarization $) * \Delta$ (money base) for deposits

Loan dollarization*(1-loan dollarization $)^{*} \Delta$ (money base) for credits

First difference of banks' net foreign assets, measured as the ratio of banks' foreign

assets minus external liabilities to total domestic deposits [IFS and NCB]

Error correction process that indicates convergence after shocks as constructed by

Honohan (2007): trend of deposit (loan) dollarization minus twice lagged value of deposit (loan) dollarization for deposits (credits)

Deposit and loan interest rate differentials (local currency - foreign currency) [IFS and NCB]

V[Inflation] / Cov(Inflation, $\Delta$ (Exchange Rate)) as constructed by Levy-Yeyati (2006), or $\{$ Corr[Inflation, $\Delta($ Exchange Rate $)] * \operatorname{StdDev}($ Inflation $)\} / \operatorname{StdDev}[\Delta($ Exchange

Rate)] as constructed by Rennhack and Nozaki (2006)

First difference of the inflation rate (as defined below) [IFS]

Index of asymmetry of exchange rate movements as constructed by Rennhack and

Nozaki (2006): assigning a value of -1 in months of currency appreciation and 1 in months of currency depreciation

Indicator of exchange rate intervention as constructed by Barajas and Morales (2003):

$(\Delta \text { int_res } / \mathrm{M} 2)^{2} /\left((\text { First Difference }(\text { Exchange Rate }) / \text { Exchange Rate })^{2}+(\Delta \text { int_res/M2 })^{2}\right)$

Volume-based measure of international financial integration as constructed by Lane and Milesi-Ferretti (2007): (total external assets + total external liabilities) / GDP

ICRG index of corruption [PRS Group]

Dummy variable that takes the value of 0 before full membership to the EU and 1

afterwards [http://europa.eu/abc/history]

Maximum value of inflation rate (as defined below) [IFS]

Maximum value of change in the exchange rate (as defined below) [IFS]

Dummy variable that takes the value of 1 during August-December 1998 and 0

otherwise.

Dummy variable that takes the value of 0 before the beginning of the EU accession process and 1 afterwards [http://europa.eu/abc/history]

Dummy variable that takes the value of 0 before the date decided by the EU for negotiating countries to join the EU and 1 afterwards [http://europa.eu/abc/history] Dummy variable that takes the value of 1 when there are restrictions on residents holdings of onshore foreign currency deposits and 0 otherwise [AREAR, IMF]

Logarithmic difference of the nominal official exchange rate (national currency/USD) [IFS]

Logarithmic difference of the CPI [IFS] 
Trend of dollarization

$\Delta$ (Money base)

$\Delta$ int_res

M2

$\Delta \mathrm{i}$-dom

$\Delta \ln \mathrm{M} 2$

$\Delta \operatorname{lnIP}$

$\mathrm{V}$ [Inflation $]$

$\mathrm{V}[\Delta($ Exchange rate $)]$
The predicted value of deposit (loan) dollarization when regressed on nonlinear time terms: time, time ${ }^{2}$, time $^{3}, \ldots$ (differs for each country; see Figure 5)

Logarithmic difference of the money base or reserve money [IFS]

First difference of international reserves [IFS]

Broad money (M2) [IFS]

First difference of local currency interest rate [IFS and NCB]

Logarithmic difference of broad money (M2) [IFS]

Logarithmic difference of index of industrial production [IFS and NCB]

Variance of the inflation rate (as defined above)

Variance of change in the exchange rate (as defined above) 